\title{
Endogenous Nociceptin (Orphanin FQ) Suppresses Basal Hedonic State and Acute Reward Responses to Methamphetamine and Ethanol, but Facilitates Chronic Responses
}

\author{
Kazuto Sakoori' and Niall P Murphy*, I \\ 'Neuronal Circuit Mechanisms Research Group, RIKEN Brain Science Institute, Wakoshi, Saitama, Japan
}

\begin{abstract}
The opioid peptide nociceptin (orphanin FQ) suppresses drug reward, drug self-administration, and impedes some of the processes believed to underlie the transition to addiction. As virtually all previous studies have used administration of nociceptin receptor agonists to evaluate the role of nociceptin on addiction-like behavior, the current study used a pharmacological (nociceptin receptor antagonist) and genetic (nociceptin receptor knockout mice) approach to elucidate the role of endogenous nociceptin. The nociceptin receptor antagonist UFP- $10 \mathrm{I}$ induced a modest place preference, and enhanced the conditioned place preference induced by methamphetamine. In agreement with this, nociceptin receptor knockout mice had slightly enhanced methamphetamine and ethanol conditioned place preferences compared to wild-type mice. This effect did not appear to depend on differences in learning ability, as nociceptin receptor knockout mice had slightly weaker-conditioned place aversions to lithium chloride, the $\kappa$-opioid receptor agonist, U50488H, and the general opiate antagonist, naloxone. The development of behavioral sensitization to methamphetamine was lower in nociceptin receptor knockout mice, and attenuated by UFP-IOI administration to wild-type mice. Additionally, ethanol consumption and preference in a two-bottle choice test was lower in nociceptin receptor knockout mice, though ethanol-stimulated locomotion was stronger. Whereas the rewarding effect of methamphetamine and ethanol following chronic treatment, as measured by place conditioning, strengthened in wild-type mice, this effect was absent in nociceptin receptor knockout mice. These results suggest that endogenous N/OFQ suppresses basal and drug-stimulated increases in hedonic state, and plays either a permissive or facilitatory role in the development of addiction.

Neuropsychopharmacology (2008) 33, 877-89I; doi:I0.1038/sj.npp. I 301459; published online 23 May 2007
\end{abstract}

Keywords: addiction; reward; opioid; methamphetamine; ethanol

\section{INTRODUCTION}

Nociceptin (known also as orphanin $\mathrm{FQ}$, abbreviated here to $\mathrm{N} / \mathrm{OFQ}$ ) is the most recently discovered member of the opioid peptide family. N/OFQ exerts its actions selectively through a cognate receptor known as the NOP receptor. A large amount of evidence suggests that targeting the $\mathrm{N} /$ OFQ-NOP receptor system may be helpful in the treatment of psychiatric disorders, such as depression, anorexia, and anxiety (see Reinscheid, 2006).

Addictive disorders have been the most studied of the psychiatric disorders that may be treatable by manipulation of the N/OFQ-NOP receptor system. The main evidence

\footnotetext{
*Correspondence: Dr NP Murphy, Neuronal Circuit Mechanisms Research Group, RIKEN Brain Science Institute, 2-I Hirosawa, Wakoshi, Saitama 35I-0198, Japan, Tel: +8I 48467 7126, Fax: +8I 48467 7|45, E-mail: nmurphy@riken.jp

Received 21 December 2006; revised 15 March 2007; accepted 17 April 2007
}

supporting the use of this strategy is summarized as follows: (1) N/OFQ or synthetic NOP receptor agonists suppress reward, as measured by the acquisition of conditioned place preference (CPP, a behavioral model used for assessing the rewarding properties of stimuli, see Bardo and Bevins, 2000), induced by cocaine (Sakoori and Murphy, 2004), morphine (Murphy et al, 1999; Ciccocioppo et al, 2000; Ciccocioppo et al, 2003; Sakoori and Murphy, 2004; Shoblock et al, 2005), ethanol (Ciccocioppo et al, 1999; Kuzmin et al, 2003), methamphetamine (METH, Zhao et al, 2003), and amphetamine (Kotlinska et al, 2003). (2) N/OFQ suppresses the development of cocaine- (Lutfy et al, 2002) and amphetamine-induced behavioral sensitization (Kotlinska et al, 2003); a phenomenon believed to model some aspects of drug craving and psychosis (see Robinson and Berridge, 2001). (3) N/OFQ suppresses oral or instrumental ethanol self-administration and reinstatement of ethanol self-administration (Ciccocioppo et al, 1999, 2002, 2003, 2004a, 2006; Economidou et al, 2006). (4) N/OFQ blocks increases in mesolimbic dopamine release induced by 
morphine (Di Giannuario et al, 1999) or cocaine (Lutfy et al, 2001).

Virtually all of the above studies have examined the effect of exogenously administered NOP receptor agonists and therefore do not provide direct evidence of a physiological function for endogenously occurring N/OFQ. The current study aimed specifically at understanding the physiological function of endogenous N/OFQ in the expression of reward and the development of addiction. To this end, we (1) investigated the influence of endogenous N/OFQ on basal and drug-stimulated increases in hedonic state (defined here as a balanced affective, emotional, and motivational state); (2) studied the influence of endogenous N/OFQ on the development of behavioral (locomotor) sensitization; (3) studied the influence of endogenous N/OFQ on ethanol reward; (4) studied the effect of chronic METH or ethanol administration on the subsequent rewarding value of METH or ethanol, respectively, and the influence that endogenous $\mathrm{N} / \mathrm{OFQ}$ may have in this effect. This study was based on the understanding that some effects of chronic drug administration may not manifest themselves as sensitized locomotion or voluntary drug intake, but rather as enhanced reward value (Lett, 1989; Shippenberg and Heidbreder, 1995a, b).

\section{MATERIALS AND METHODS}

\section{Experimental Animals}

Experimental protocols were approved by the RIKEN Brain Science Institute review committee and were in accord with the National Research Council Guide for the Care and Use of Laboratory Animals. Male C57BL6 mice (Nihon Clea, Tokyo, Japan) were used for NOP receptor antagonist experiments. For other experiments, male and female wildtype and NOP receptor knockout (KO) mice (Nishi et al, 1997) were generated and housed as described previously (Koizumi et al, 2004a). The NOP receptor KO mouse colony had been backcrossed 10 times onto a C57BL6 background. Male mice were used in all METH studies. Female mice were used in ethanol studies.

\section{Surgical Procedures and Drugs}

Where appropriate, mice underwent stereotaxic surgery under ketamine/xylazine anesthesia for implantation of a chronic indwelling intracerebroventricular (i.c.v.) cannula into the lateral cerebroventricle. Details of the surgical procedure, injection methodology, and drugs used throughout the study are provided as Supplementary Materials and Methods.

\section{Place-Conditioning Apparatus and Measurement of Locomotion}

Mice were place-conditioned using a randomized unbiased design in a two-compartment apparatus as described previously (Sakoori and Murphy, 2004). Further details of the design of the place-conditioning apparatus and locomotor arenas used for behavioral sensitization studies are provided as Supplementary Materials and Methods.

\section{Experiment 1: Place Conditioning by the NOP Receptor Antagonist UFP-101}

In order to address the question of the influence of endogenous N/OFQ on basal hedonic balance, C57BL6 mice (aged 10 weeks) were conditioned four times with the peptide NOP receptor antagonist UFP-101 at doses of 0.1-10 nmol i.c.v. (four $0.9 \% \mathrm{NaCl}$ vehicle and four UFP-101-conditioning sessions, day 2 to day 9). As our previous studies show that place conditioning often incubates over time (Sakoori and Murphy, 2005), the establishment of place conditioning was tested twice, the day following conditioning (test 1 on day 10) and 30 days later (test 2 on day 39 ).

\section{Experiment 2: Effect of the NOP Receptor Antagonist UFP-101 on METH-Induced CPP}

To allow identification of any interaction between endogenous N/OFQ and drug-stimulated increases in hedonic state, C57BL6 mice (aged 10 weeks) were conditioned four times with either METH alone ( $2 \mathrm{mg} / \mathrm{kg}$ subcutaneous, s.c.), UFP-101 (10 nmol i.c.v.), or a combination of both in the same manner as Experiment 1. The establishment of place conditioning was tested once, the day following the last conditioning session (day 10).

\section{Experiment 3: Drug-Induced Place Conditioning in NOP Receptor KO Mice}

With the aim of seeking further support for a role of endogenous N/OFQ in determining hedonic responses (both positive and negative), we studied place conditioning in NOP receptor KO mice. For this experiment, NOP receptor $\mathrm{KO}$ and wild-type mice (aged 12 weeks) were conditioned twice over 4 days (two $0.9 \% \mathrm{NaCl}$ vehicle and two drug-conditioning sessions) to either s.c. injection of METH $(2 \mathrm{mg} / \mathrm{kg}), \mathrm{LiCl}(127 \mathrm{mg} / \mathrm{kg}$ administered at a $0.2 \mathrm{ml} /$ $10 \mathrm{~g}$ body weight), naloxone $(5 \mathrm{mg} / \mathrm{kg})$, or U50,488H $(2 \mathrm{mg} /$ $\mathrm{kg}$ ). Place conditioning was tested twice - the next day (test 1 on day 6), and again 5 days later (test 2 on day 11).

\section{Experiment 4: METH-Induced Behavioral Sensitization in NOP Receptor KO Mice}

To obtain an understanding of the role of endogenous N/OFQ in the processes underlying behavioral sensitization to METH in a novel environment, NOP receptor $\mathrm{KO}$ and wild-type mice (aged 24 weeks) were studied. Mice were administered METH ( $1 \mathrm{mg} / \mathrm{kg}$ s.c.) and locomotion was immediately measured for $30 \mathrm{~min}$. This procedure was repeated for 14 days (day 1-14). Eighteen and 22 days after the last daily METH treatment, mice were challenged with $1 \mathrm{mg} / \mathrm{kg}$ (day 32) and $2 \mathrm{mg} / \mathrm{kg}$ METH (day 36), respectively, following a $30 \mathrm{~min}$ baseline measurement period to determine possible differences in conditioned locomotion. Subsequently, METH-stimulated locomotion was measured for $90 \mathrm{~min}$.

\section{Experiment 5: Effect of the NOP Receptor Antagonist UFP-101 on METH-Induced Behavioral Sensitization}

In order to further seek support for a role of endogenous $\mathrm{N} / \mathrm{OFQ}$ in the processes underlying behavioral sensitization, 
the effect of UFP-101 on the development of behavioral sensitization to METH was studied. On the first day of the experiment (day 0), the basal locomotion of C57BL6 mice (aged 10 weeks) was measured for $30 \mathrm{~min}$ to establish all treatment groups were equal. The following 8 days (day 1 to day 8 ), mice received daily i.c.v. injections of $0.9 \% \mathrm{NaCl}$ vehicle or $5 \mathrm{nmol}$ UFP-101 immediately before s.c. injection of $1 \mathrm{mg} / \mathrm{kg}$ METH. Locomotion was immediately measured for $30 \mathrm{~min}$. Four or 5 days, and 9 or 10 days after the daily injection phase, mice were challenged with $1 \mathrm{mg} / \mathrm{kg}$ (day 12 or day 13) and $2 \mathrm{mg} / \mathrm{kg} \mathrm{METH}$ (day 17 or day 18) and locomotion was measured for $90 \mathrm{~min}$, after a $30 \mathrm{~min}$ period to measure basal locomotion. Data for days 12 and 13 were averaged, as were data for days 17 and 18 .

\section{Experiment 6: Effects of Chronic METH Treatment on METH-Induced CPP in NOP Receptor KO Mice}

With the aim of understanding the role of endogenous $\mathrm{N} / \mathrm{OFQ}$ in the development of changes in the incentive or rewarding value of METH during chronic treatment, two independent sets of NOP receptor $\mathrm{KO}$ and wild-type mice (aged 16 weeks) were administered either s.c. $0.9 \% \mathrm{NaCl}$ vehicle or $1 \mathrm{mg} / \mathrm{kg}$ METH daily for 12 days in their home cages. Following this, mice underwent place conditioning to two administrations of METH over 4 days (two vehicle- and two drug-conditioning sessions). For this part of the study, an intermediate dose of s.c. $1.5 \mathrm{mg} / \mathrm{kg} \mathrm{METH}$ was chosen in order to establish a moderate level of place conditioning over which decreases or increases in place-conditioning strength could be observed.

\section{Experiment 7: Chronic Ethanol Responses in NOP Receptor KO Mice}

In order to understand the role of endogenous N/OFQ in the response to chronic ethanol administration, wild type and NOP receptor KO mice (aged 35 weeks) were administered an intraperitoneal (i.p.) $2 \mathrm{~g} / \mathrm{kg}$ dose of ethanol daily and locomotion measured for $10 \mathrm{~min}$ in a novel environment for 14 days (days 1 to 14). Three (day 17) and 5 days (day 19) after the last injection, mice were challenged with i.p. $1 \mathrm{~g} / \mathrm{kg}$ and $2 \mathrm{~g} / \mathrm{kg}$ ethanol, respectively and locomotion measured. Before ethanol administration on the challenge days, basal locomotion was measured for $30 \mathrm{~min}$. Ethanol-stimulated locomotion was measured for $30 \mathrm{~min}$. Six more (day 25) and 8 (day 27) more days later, mice were challenged with s.c. $1 \mathrm{mg} / \mathrm{kg}$ and $2 \mathrm{mg} / \mathrm{kg} \mathrm{METH}$, respectively to examine if cross-tolerance or cross-sensitization occurred. Similar to days 25 and 27, basal locomotion was measured for $30 \mathrm{~min}$, followed by drug-stimulated locomotion for $60 \mathrm{~min}$.

\section{Experiment 8: Ethanol Preference and Sedative Effects of Ethanol in NOP Receptor KO Mice: Two-Bottle Choice Experiment}

Mice (aged 14 weeks) were first compared in their sedative response (loss-of-righting reflex) to an i.p. $3 \mathrm{~g} / \mathrm{kg}$ dose of ethanol. Thus, animals were injected ethanol and tested by supine placement in $\mathrm{V}$-shaped (approximately $90^{\circ}$ ) plastic troughs. The latency to loss-of-righting reflex following ethanol injection and time to spontaneous postural righting was measured. Righting was judged complete when animals were able to regain correct posture three times within $30 \mathrm{~s}$.

Three days after the test of loss-of-righting reflex, mice were housed individually and habituated to drinking water from two bottles in the home cage before the beginning of the test. Animals were initially presented a choice between water and $3 \%$ ethanol. Every 7 days, the concentration of the ethanol solution was increased according to the following sequence: 6,10 , and $20 \%$. The weight of each solution consumed was recorded daily. The position (left or right) of each bottle was changed daily to avoid side preference. Body weight and total food intake for each 7-day period was recorded at the time of changing the ethanol concentration. Almost 1 month later, taste reactivity to saccharine and quinine was compared by presentation of an unrestricted choice of saccharine sodium salt $(0.033$ and $0.066 \%, \mathrm{w} / \mathrm{v})$ or quinine $(0.015$ and $0.033 \mathrm{mM})$ against water. Each concentration was presented for 4 days and the bottle position changed daily. Within each tastant, the low concentration was presented first, followed by the high concentration. The order of presentation of the two tastants was counterbalanced within and between groups. Mice used in this experiment were studied in a CPP Experiment 18 days after the end of this experiment (Experiment 9).

\section{Experiment 9: Ethanol-Induced Place Conditioning in NOP Receptor KO Mice}

In order to understand the role of endogenous N/OFQ in the development of changes in the incentive or rewarding value of ethanol during chronic treatment, ethanol-naive NOP receptor $\mathrm{KO}$ and wild-type mice (ethanol-naive group, aged 12 weeks) were compared to the mice studied in Experiment 8 (ethanol experienced group, aged 34 weeks at the time of this part of the experiment) in their response to ethanolinduced place conditioning. Mice were conditioned four times with either $0.9 \% \mathrm{NaCl}$ vehicle or ethanol (2 g/kg i.p., four vehicle and four ethanol-conditioning sessions). Place conditioning was tested the day immediately following conditioning. Eleven days after completion of the placeconditioning experiment, all mice from the original ethanolnaive group were administered an i.p. $4 \mathrm{~g} / \mathrm{kg}$ injection of ethanol in order to assess blood ethanol clearance. Mice were killed at either 15 or $60 \mathrm{~min}$ following the injection and plasma ethanol was measured using a commercially available coupled alcohol dehydrogenase/acetaldehyde dehydrogenase assay kit (Boehringer Mannheim, Tokyo, Japan).

\section{Data and Statistical Analysis}

Details of statistical analyses are provided where appropriate below and elaborated in Supplementary Materials and Methods.

\section{RESULTS}

Experiment 1: Place Conditioning by the NOP Receptor Antagonist UFP-101

Following the conditioning period, mice conditioned with $1 \mathrm{nmol}$ UFP-101 showed a mild CPP on the test performed 
the day after the final conditioning sessions (Figure 1a), though this was not statistically significant when Bonferroni-adjusted $\left(t_{(6)}=-2.743, p=0.0336\right)$. Although it was not statistically significant, a continued tendency toward a CPP was observed in $1 \mathrm{nmol}$ UFP-101-conditioned mice during the second test performed 29 days later. However, mice conditioned with $10 \mathrm{nmol}$ UFP-101 showed a significant $\left(t_{(6)}=-3.317, p=0.0161\right)$ CPP during the second test (Figure 1a).

\section{Experiment 2: Effect of the NOP Receptor Antagonist UFP-101 on METH-Induced CPP}

Mice conditioned with $2 \mathrm{mg} / \mathrm{kg}$ METH alone showed a statistically significant $\left(t_{(10)}=-4.173, p=0.0019\right)$ CPP for the drug-paired compartment on the day immediately following the final conditioning sessions, whereas unlike Experiment 1, UFP-101-only-conditioned groups did not show any statistically significant place conditioning (Figure 1b). Mice conditioned with both $2 \mathrm{mg} / \mathrm{kg}$ METH and $10 \mathrm{nmol}$ UFP-101 showed a significant CPP $\left(t_{(9)}=\right.$ $-9.247, p<0.0001$ ), which was statistically significantly larger than mice conditioned with METH alone (difference scores: METH-vehicle group; $111.0 \pm 26.6 \mathrm{~s}$, METH-UFP-101 group; $\left.184.5 \pm 19.9 \mathrm{~s}, t_{(19)}=-2.175, p=0.0425\right)$.
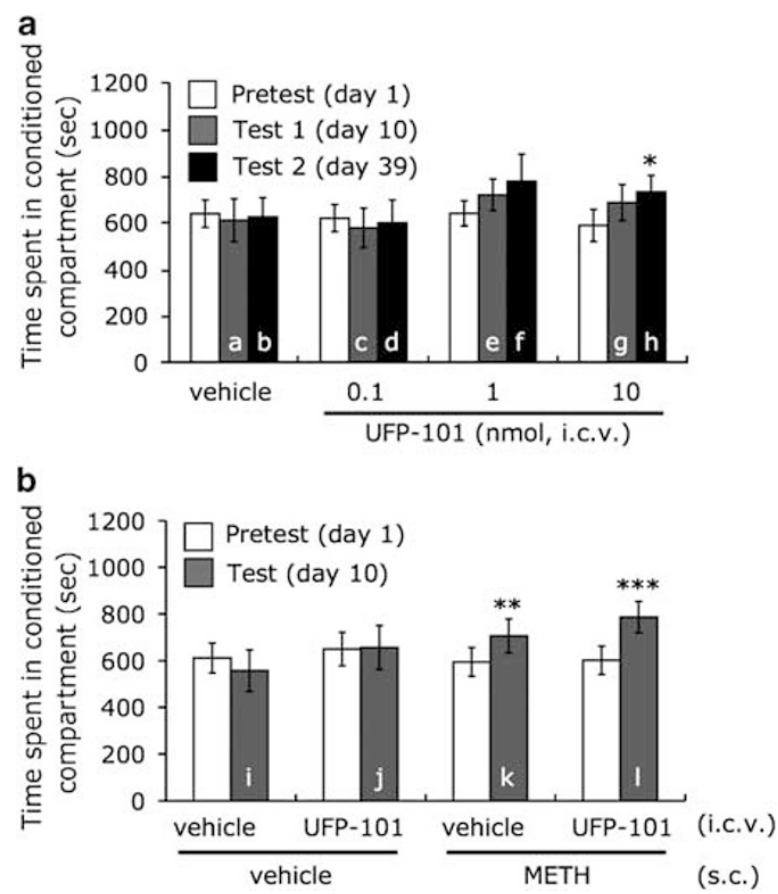

Figure I Place conditioning to (a) the NOP receptor antagonist UFP$10 \mid$ and (b) coadministration of 10 nmol UFP-IOI on methamphetamine $(\mathrm{METH})(2 \mathrm{mg} / \mathrm{kg}$ s.c.). $Y$ axis represents time in the drug-paired compartment before (pretest) and after (test) conditioning four times to vehicle and four times to drugs on alternating days. The $\alpha$ value for data shown in panel a was Bonferroni-adjusted to 0.025 , whereas the $\alpha$ value for data shown in panel $b$ was set at 0.05. ${ }^{*} p<0.025$, *** $<<0.01$, and **** $p<0.00$ I vs corresponding pretest time. $n=7-1$ I mice per group. Data are presented as mean \pm SEM. A detailed report of the statistical analyses indicated by lowercase letters is provided online as Supplementary Information.
Experiment 3: Drug-Induced Place Conditioning in NOP Receptor KO Mice

Neither wild type nor NOP receptor KO vehicle-treated mice showed significant place conditioning (Figure 2). METH $(2 \mathrm{mg} / \mathrm{kg}$ s.c.) conditioning induced a significant CPP in both genotypes on the first test performed the day immediately following conditioning $\left(t_{(11)}=-3.568\right.$, $p=0.0044$ for wild-type mice; $t_{(9)}=-4.496, p=0.0015$ for NOP receptor KO, Figure 2). However, a statistically significant CPP was maintained only in NOP receptor $\mathrm{KO}$ mice during the second test performed 5 days later $\left(t_{(11)}=-2.112, \quad p=0.0584\right.$ for wild-type mice; $t_{(9)}=$ $-4.295, p=0.0020$ for NOP receptor KO mice). Conditioning with s.c. $127 \mathrm{mg} / \mathrm{kg} \mathrm{LiCl}$ established a mild-conditioned place aversion in NOP receptor KO mice during the first test (Figure 2), though this was not statistically significant when Bonferroni adjusted $\left(t_{(10)}=2.354, p=0.0404\right.$ for NOP receptor KO mice). Wild-type mice showed no conditioned place aversion to $\mathrm{LiCl}$ during the first test, whereas a mildconditioned place aversion was observed during the second test, which again was not statistically significant when Bonferroni adjusted $\left(t_{(10)}=2.514, p=0.0386\right)$. A strongconditioned place aversion to $5 \mathrm{mg} / \mathrm{kg}$ naloxone was observed in both genotypes in the first test $\left(t_{(8)}=6.982\right.$, $p=0.0001$ for wild-type mice; $t_{(8)}=6.065, p=0.0003$ for NOP receptor KO mice) that was maintained in both genotypes in the second test $\left(t_{(8)}=6.601, p=0.0002\right.$ for wild-type mice; $t_{(8)}=6.036, p=0.0003$ for NOP receptor KO mice, Figure 2). Similar to naloxone-conditioned place aversion, $2 \mathrm{mg} / \mathrm{kg}$ U50488H induced a statistically significant conditioned place aversion in both genotypes in the first test $\left(t_{(9)}=4.637, p=0.0012\right.$ for wild-type mice; $t_{(9)}=5.066, p=0.0007$ for NOP receptor KO mice) that was maintained in the second test $\left(t_{(9)}=4.202, p=0.0023\right.$ for wild-type mice; $t_{(9)}=3.727, p=0.0047$ for NOP receptor KO mice, Figure 2).

\section{Experiment 4: METH-Induced Behavioral Sensitization in NOP Receptor KO Mice}

When both genotypes were analyzed together by repeated measures analysis of variance (ANOVA), a statistically significant interaction of genotype and treatment day $\left(\mathrm{F}_{(13,234)}=2.10, p=0.0149\right)$ was found, though no significant main effect of genotype $\left(\mathrm{F}_{(1,234)}=2.230, p=0.1527\right)$ was observed. Notably, in a separate experiment detailed below (Experiment 7), there was no difference between wild type and NOP receptor KO mice in response to repeated vehicle administration. That is, both genotypes habituated to repeated vehicle administration at similar rates. Both wild type and NOP receptor KO mice showed a progressive increase in the locomotor response to $1 \mathrm{mg} / \mathrm{kg} \mathrm{METH}$ as shown by a significant effect of time when analyzed individually by repeated measures ANOVA (wild type, $\mathrm{F}_{(13,117)}=$ $10.56, p<0.0001$; NOP receptor KO, $\left.\mathrm{F}_{(13,117)}=2.799, p=0.0016\right)$, indicating behavioral sensitization had occurred in both groups (Figure $3 \mathrm{a}$ ).

No significant main effect of genotype or interaction between genotype and within session time on locomotion in either the $30 \mathrm{~min}$ basal or $60 \mathrm{~min}$ postdrug period was observed when mice were challenged with $1 \mathrm{mg} / \mathrm{kg}$ 


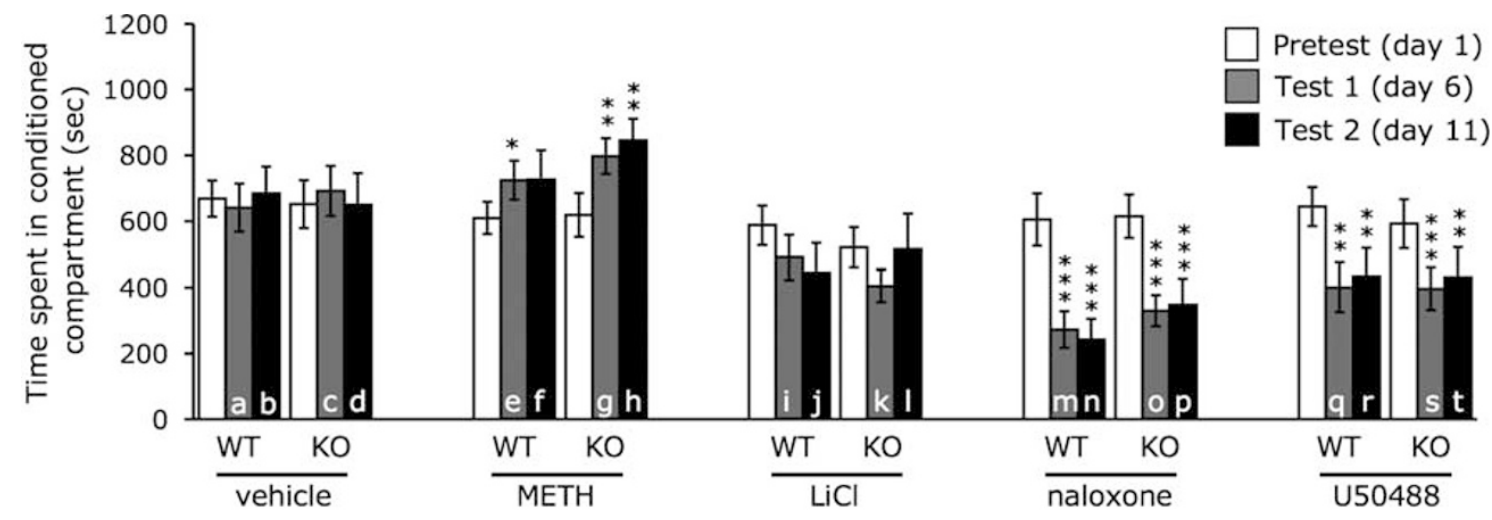

Figure 2 Place conditioning to various drugs in wild type (WT) and NOP receptor knockout $(\mathrm{KO})$ mice. Drug conditioning doses were as follows: methamphetamine (METH), $2 \mathrm{mg} / \mathrm{kg}$ s.c.; LiCl, $127 \mathrm{mg} / \mathrm{kg}$ s.c.; naloxone, $5 \mathrm{mg} / \mathrm{kg}$ s.c., U50488; $2 \mathrm{mg} / \mathrm{kg}$ s.c. $Y$ axis represents time in the drug-paired compartment before (pretest) and after (test) conditioning twice to vehicle and twice to drugs on alternating days. The $\alpha$ value was Bonferroni-adjusted. ${ }^{*} p<0.025$, ** $p<0.005$, and $* * * p<0.0005$ vs corresponding pretest time. $n=9$ to 15 mice per group. Data are presented as mean \pm SEM. A detailed report of the statistical analyses indicated by lowercase letters is provided online as Supplementary Information.

METH 18 days later (day 32, Figure 3b). Although a direct comparison of the locomotion between days 1-14 and day 32 was not possible due to the addition of a basal locomotion-measuring period on day 32 , the amount of locomotion expressed in the $30 \mathrm{~min}$ period following administration of $1 \mathrm{mg} / \mathrm{kg} \mathrm{METH}$ on day 32 was similar to that observed on day 14 , but greater than observed on day 1 . This suggested that no further sensitization had taken place between day 14 and day 32 . Four more days later (day 36, Figure 3c), mice were challenged with $2 \mathrm{mg} / \mathrm{kg}$ METH. Again, no statistically significant main effect or interaction of genotype and time was observed in the $30 \mathrm{~min}$ basal measuring period before injection. However, a significant interaction between genotype and time in the $60 \mathrm{~min}$ post- $2 \mathrm{mg} / \mathrm{kg} \mathrm{METH}$ period was found $\left(\mathrm{F}_{(11,198)}=1.852, p=0.0479\right)$, due to NOP receptor KO mice showing a weaker METH-stimulated locomotion than wild-type mice (Figure 3c), again indicating that NOP receptor KO mice had not sensitized as well as wild-type mice to METH. No main effects were observed during this period.

\section{Experiment 5: Effect of the NOP Receptor Antagonist UFP-101 on METH-Induced Behavioral Sensitization}

No significant differences in basal locomotion between groups on day 0 were observed before drug treatment (Figure 3d). UFP-101 administration strongly suppressed locomotion in general (Figure 3d), though both groups of mice showed a progressive increase in locomotion between days 1 and 8. The strong suppressive effect of UFP-101 on METH-stimulated locomotion precluded any clear conclusion on the effect of UFP-101 on the development of behavioral sensitization. Notably, little tolerance to the suppressive effect of repeated administration of UFP-101 alone on locomotion was observed during the place-conditioning studies of Experiment 1 suggesting that the progressive increase in locomotion observed in mice treated with METH and UFP101 was not simply due to a gradual development of tolerance to UFP-101. Repeated measures ANOVA showed a significant main effect of UFP-101 treatment $\left(\mathrm{F}_{(1,20)}=42.172, p<0.0001\right)$ reflecting its suppressive effects, and a significant main effect of treatment day $\left(\mathrm{F}_{(7,140)}=10.718, p<0.0001\right)$ reflecting a general increase in locomotion in both treatment groups over the 8 days of measurement. A significant interaction between UFP-101 treatment and treatment day $\left(\mathrm{F}_{(7,140)}=3.053, p=0.0051\right)$ on locomotion was also observed, indicating that the rate of change in locomotion differed between the treatment groups. This was particularly apparent as a decrease in locomotion between the day 1 and day 2 in mice administered UFP-101 and METH, whereas mice administered METH alone showed an increase in locomotion during this period.

Mice previously treated with UFP-101 and METH during the development phase showed significantly lower basal and stimulated locomotion when challenged with $1 \mathrm{mg} / \mathrm{kg}$ METH 4 or 5 days later (days 12 or 13, Figure $3 e$ ), compared with mice treated with vehicle during the development phase. Repeated measures ANOVA showed a significant main effect of previous UFP-101 treatment $\left(\mathrm{F}_{(1,20)}=11.885, p=0.0025\right)$ and interaction between previous UFP-101 treatment and time $\left(\mathrm{F}_{(5,100)}=2.551\right.$, $p=0.0324$ ) during the basal $30 \mathrm{~min}$ locomotion period. A significant main effect of previous UFP-101 treatment $\left(\mathrm{F}_{(1,20)}=9.434, p=0.0060\right)$ and interaction between previous UFP-101 treatment and time $\left(\mathrm{F}_{(11,220)}=2.295\right.$, $p=0.0112$ ) on locomotion was also observed during the postdrug $90 \mathrm{~min}$ period, indicating that prior UFP-101 administration attenuated the development of behavioral sensitization.

No effect of previous UFP-101 treatment on baseline locomotion was observed a further 5 days later (Figure 3f), nor was there any interaction with $2 \mathrm{mg} / \mathrm{kg} \mathrm{METH}$ challenge, though similar to the first METH challenge, mice previously treated with UFP-101 continued to show a trend toward lower METH-stimulated locomotion.

\section{Experiment 6: Effects of Chronic METH Treatment on METH-Induced CPP in NOP Receptor KO Mice}

Following 12 daily administrations of vehicle, NOP receptor KO mice, but not wild-type mice, showed a statistically 


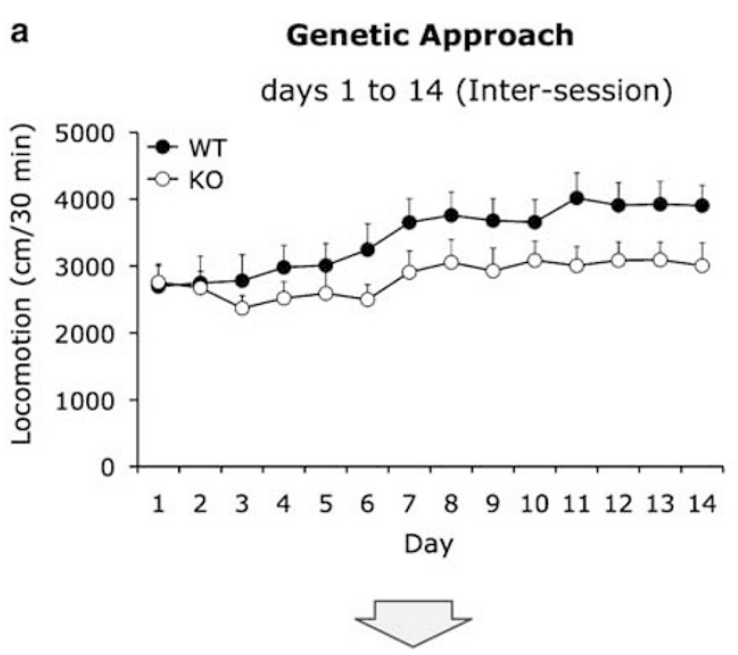

\section{d \\ Pharmacological Approach}
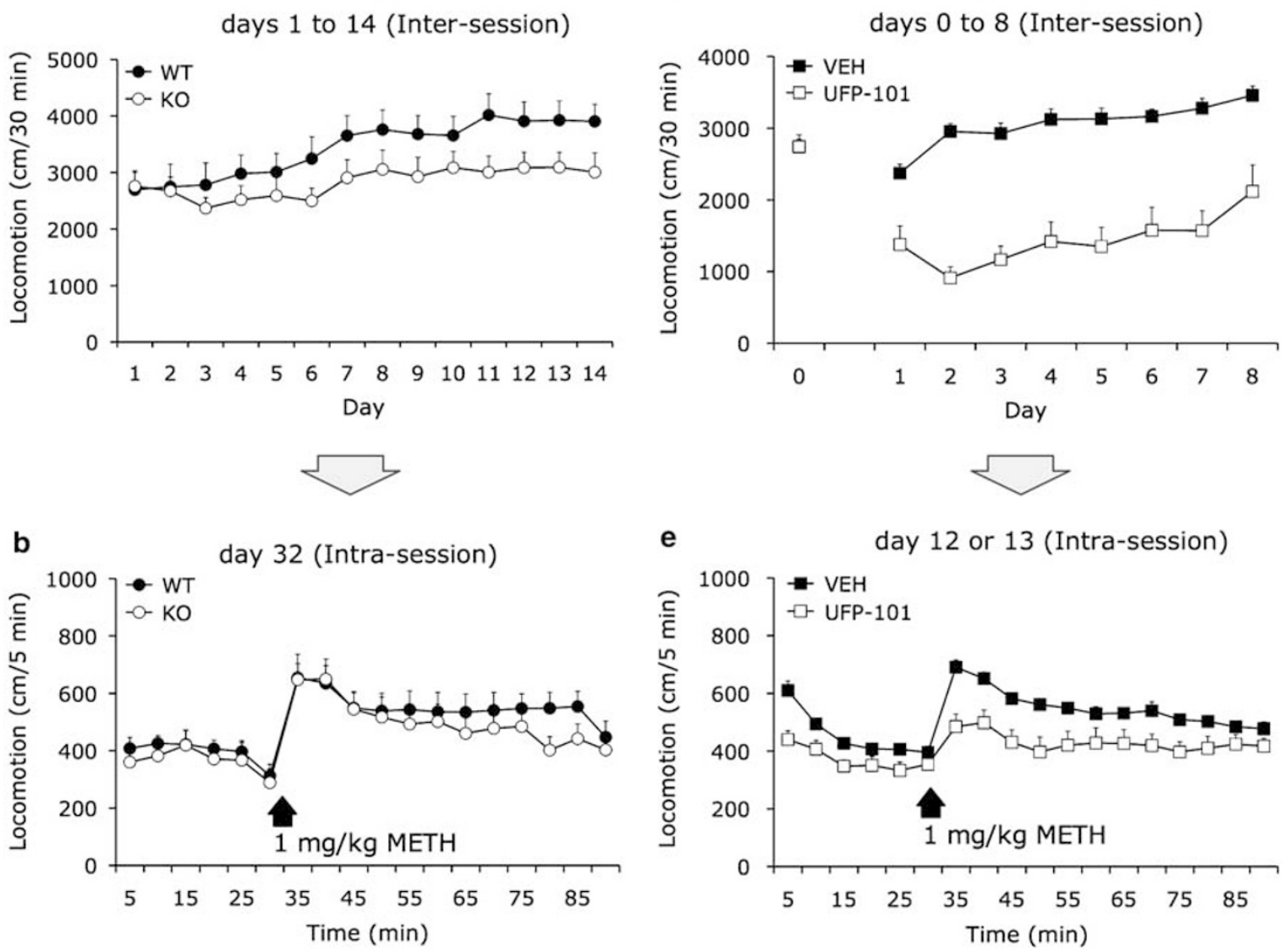

e

day 12 or 13 (Intra-session)
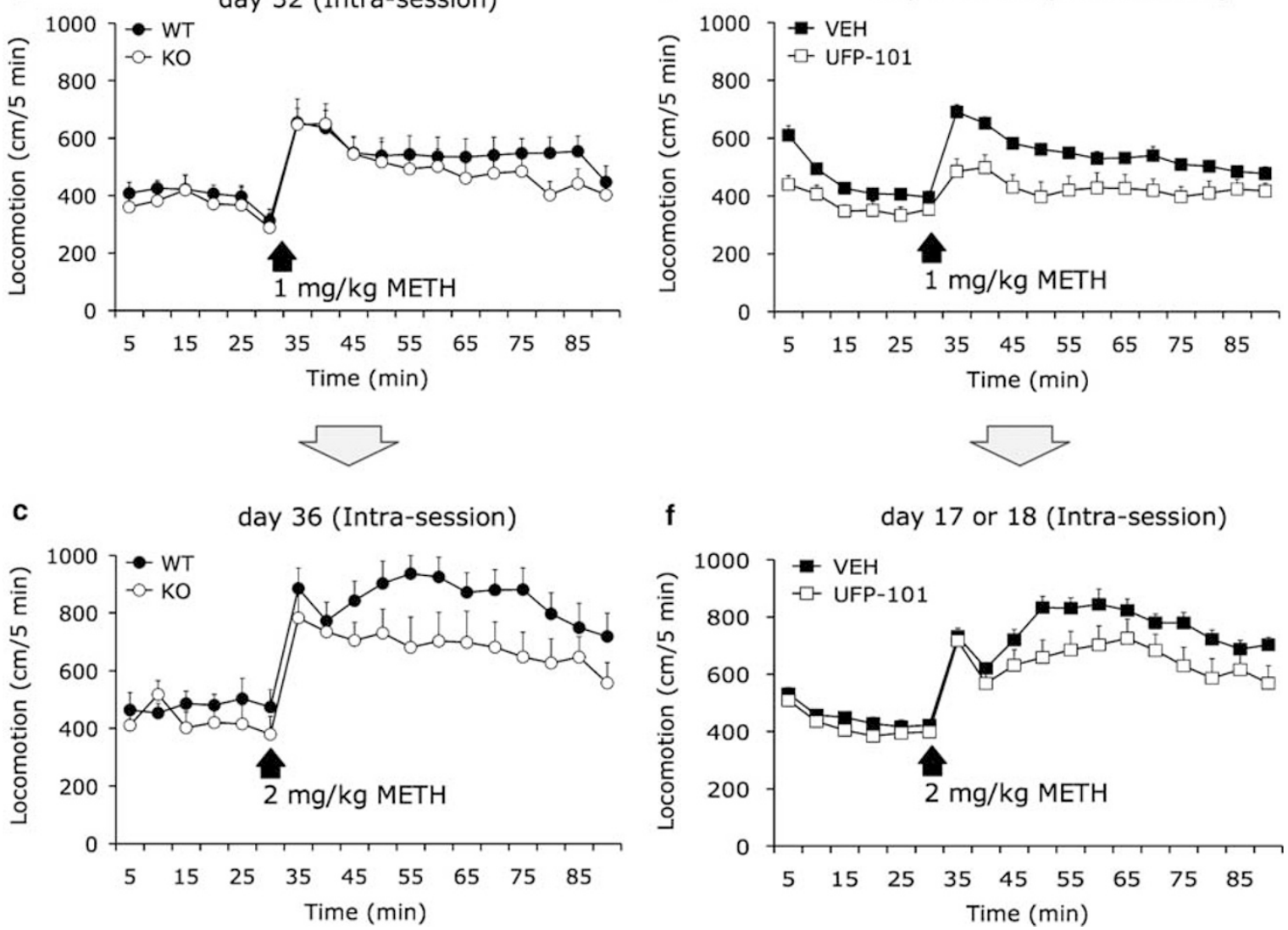

Figure 3 Effect of NOP receptor gene deletion $(\mathrm{a}-\mathrm{c}$ ) and the NOP receptor antagonist UFP-IOI ( $\mathrm{d}-\mathrm{f}$ ) on the development of behavioral sensitization to I mg/kg s.c. methamphetamine (METH). For studies on NOP receptor knockout (KO) mice, METH was administered daily for I4 days (days I-I4) in a novel environment and mice were challenged with I mg/kg s.c. METH in the same environment I 8 days later (day 32) and with $2 \mathrm{mg} / \mathrm{kg}$ s.c. METH 4 more days (day 36) later. Panel a shows total locomotion for the entire 30 min recording session. Panels b and c show locomotion divided into 5 min bins on days 32 and 36. A 30 min basal recording period was made before METH administration on days 32 and 36 in order to assess drug-conditioned changes in basal locomotion. For studies on the effect of UFP-I 0 I on the development of behavioral sensitization, mice were recorded firstly (day 0) for 30 min without any drug treatment to ensure equal baseline locomotion (d). Subsequently, mice were administered either I mg/kg s.c. METH alone, or concurrently with $5 \mathrm{nmol}$ i.c.v. UFP-IOI for 8 days and locomotion recorded for 30 mins. Four or 5 days later (e: day 12 or I3), all mice were challenged with I mg/kg s.c. METH following a $30 \mathrm{~min}$ basal locomotor recording period. Panels e and $\mathrm{f}$ show locomotion divided into 5 min bins. Five more days later (f: days 17 or I8), mice were challenged with $2 \mathrm{mg} / \mathrm{kg}$ s.c. METH. Only 90 of the $120 \mathrm{~min}$ locomotor measurement period following drug injection is shown in panels e and for ease of comparison with panels b and c. $n=10$ or II mice per group. Data are presented as mean \pm SEM. See Results section for the results of statistical analysis.

significant $\left(t_{(11)}=-3.858, p=0.0027\right) \mathrm{CPP}$ to $1.5 \mathrm{mg} / \mathrm{kg}$ METH (Figure 4a). In contrast, both wild type and NOP receptor KO mice showed a statistically significant (wild type; $t_{(11)}=-5.664, p=0.0002, \mathrm{KO} ; t_{(9)}=-2.624$, $p=0.0276)$ CPP to $1.5 \mathrm{mg} / \mathrm{kg}$ METH following 12 daily administrations of $1 \mathrm{mg} / \mathrm{kg}$ METH (Figure $4 \mathrm{~b}$ ). However, no 

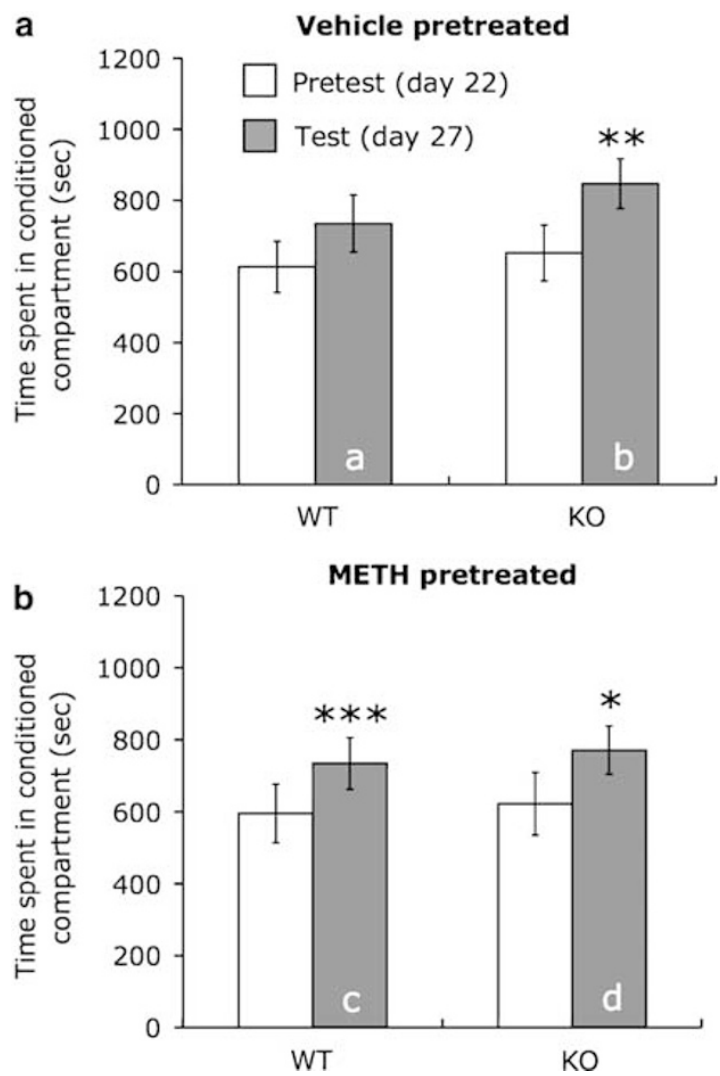

Figure 4 Effect of chronic methamphetamine (METH) treatment on $1.5 \mathrm{mg} / \mathrm{kg}$ s.c. METH-induced CPP in wild type (WT) and NOP receptor knockout $(\mathrm{KO})$ mice. Before place conditioning, mice were administered either s.c. vehicle (a) or s.c. I mg/kg METH (b) daily for 12 days in their home cages. Ten days after the final vehicle or METH administration, all mice underwent pretesting (day 22) to determine nonconditioned biases. All mice then underwent 4 days of conditioning (two vehicle and two $1.5 \mathrm{mg} / \mathrm{kg}$ s.c. METH sessions given on alternate days, days 23-26). Mice were tested for the establishment of CPP on day 27. $* p<0.05$, *** $<0.0$ I and ${ }^{*} * * p<0.001$ pretest vs corresponding pretest time. $n=10-12$ mice per group. Data are presented as mean \pm SEM. A detailed report of the statistical analyses indicated by lower case letters is provided online as Supplementary Information.

difference in the strength of the CPP was found between the genotypes in this latter case.

\section{Experiment 7: Chronic Ethanol Responses in NOP Receptor KO Mice}

Repeated measures ANOVA (genotype $\times$ drug treatment $\times$ time) revealed main effects of ethanol administration $\left(\mathrm{F}_{(1,34)}=5.449, p<0.0001\right)$ and genotype $\left(\mathrm{F}_{(1,34)}=\right.$ 78.986, $p=0.0256$ ) on locomotion. This was due to a stimulatory effect of ethanol, and an overall enhanced locomotion in NOP receptor KO mice (Figure 5a). An almost statistically significant interaction between genotype and drug treatment $\left(\mathrm{F}_{(1,34)}=3.962, p=0.0546\right)$ was observed as NOP receptor KO mice tended toward stronger locomotor response to ethanol administration than wild-type mice, whereas both genotypes showed similar locomotion following vehicle administrations. To further examine this finding, we performed repeated measures ANOVA (genotype $\times$ treatment days) separately for vehicle-or ethanol-treated mice. In this case, no genotype-dependent difference between wild type and NOP receptor KO mice was found following daily vehicle treatment. However, NOP receptor KO mice showed a higher ethanol-stimulated locomotion as revealed by a statistically significant main effect of genotype $\left(\mathrm{F}_{(1,17)}=4.995, p=0.0391\right.$, Figure 5a). Additionally, there was no main effect of treatment day, indicating no behavioral sensitization to ethanol had taken place. Nor was there a significant interaction between treatment day and genotype. When daily locomotor measurements were compacted across the 14 daily recording sessions and analyzed by ANOVA using genotype and drug treatment as main factors, significant main effects of both genotype $\left(\mathrm{F}_{(1,528)}=63.727, p<0.0001\right)$ and drug treatment $\left(\mathrm{F}_{(1,528)}=923.770, p<0.0001\right)$ were observed, as well as the interaction between genotype and drug treatment $\left(\mathrm{F}_{(1,528)}=46.335, p<0.0001\right)$.

Three days later, on day 17 (Figure 5b), mice previously chronically treated with ethanol for 14 days showed significantly higher basal locomotion (main effect of previous ethanol treatment, $\mathrm{F}_{(1,34)}=25.283, p<0.0001$ ), as well as higher locomotion following challenge with $1 \mathrm{mg} / \mathrm{kg}$ ethanol $\left(\mathrm{F}_{(1,34)}=14.476, p=0.0006\right)$. There was no genotype-dependent difference or interaction of previous ethanol treatment with genotype either before or after ethanol administration on day 17 (Figure 5b). Thus, previous ethanol treatment resulted in a conditioned locomotor response that was not dependent on genotype, nor interacted with a low challenge dose of ethanol.

Two days later, on day 19 (Figure $5 \mathrm{c}$ ), mice that had been chronically treated with ethanol on days 1-14 continued to show higher basal locomotion (main effect of previous ethanol treatment, $\left.\mathrm{F}_{(1,34)}=13.481, p=0.0008\right)$ and following administration of $2 \mathrm{~g} / \mathrm{kg}$ ethanol (main effect of previous ethanol treatment, $\mathrm{F}_{(1,34)}=22.602, p<0.0001$ ), similar to day 17. A significant main effect of genotype was found in the post-ethanol challenge period $\left(\mathrm{F}_{(1,34)}=11.270, p=0.002\right)$ though no interaction between genotype and previous ethanol treatment was found. However, NOP receptor KO mice previously treated with ethanol tended toward higher locomotion than previously ethanol-treated wild-type mice in the $30 \mathrm{~min}$ period following ethanol challenge. A significant effect of time $\left(\mathrm{F}_{(5,170)}=36.355, p<0.0001\right)$ and interaction $\left(\mathrm{F}_{(5,170)}=2.668, p=0.0238\right)$ between genotype and time was observed due to a generally falling level of activity after the peak of activity following ethanol administration, and enhanced locomotor response to ethanol (Figure 5c) in NOP receptor KO mice, as observed during the chronic ethanol treatment described above (Figure $5 \mathrm{a}$ ).

Similar to days 17 and 19, mice that had been treated with ethanol on days 1-14 had higher basal locomotion (main effect of previous ethanol treatment, $F_{(1,34)}=27.984$, $p<0.0001)$ and following administration of $1 \mathrm{mg} / \mathrm{kg}$ s.c. METH (main effect of previous ethanol treatment, $\mathrm{F}_{(1,34)}=5.766, p=0.022$ ) on day 25 (Figure $5 \mathrm{~d}$ ). However, no genotype difference or interaction of previous ethanol treatment on days 1-14 with genotype was observed. Again, mice that had received daily ethanol treatment on days 1-14 continued to show enhanced basal locomotion on day 27 (main effect of previous ethanol treatment, $\mathrm{F}_{(1,34)}=4.435$, $p=0.0427$ ), though no main genotype difference or interaction with previous ethanol treatment was found 
a
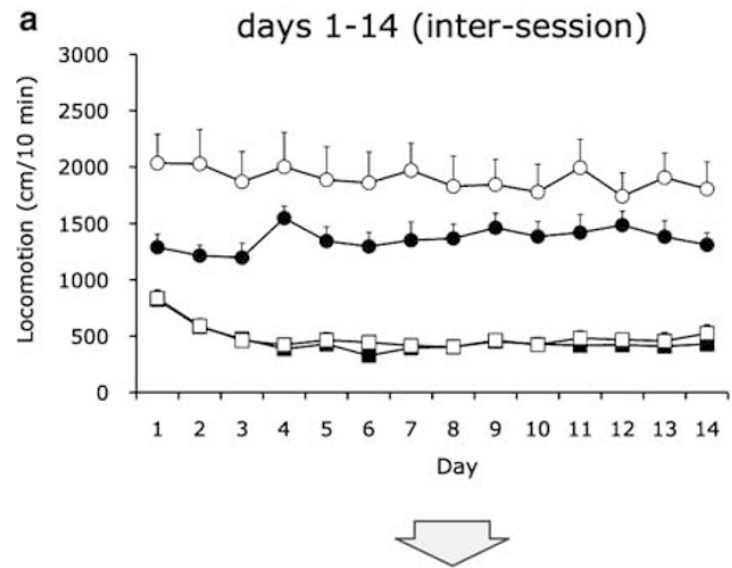

b
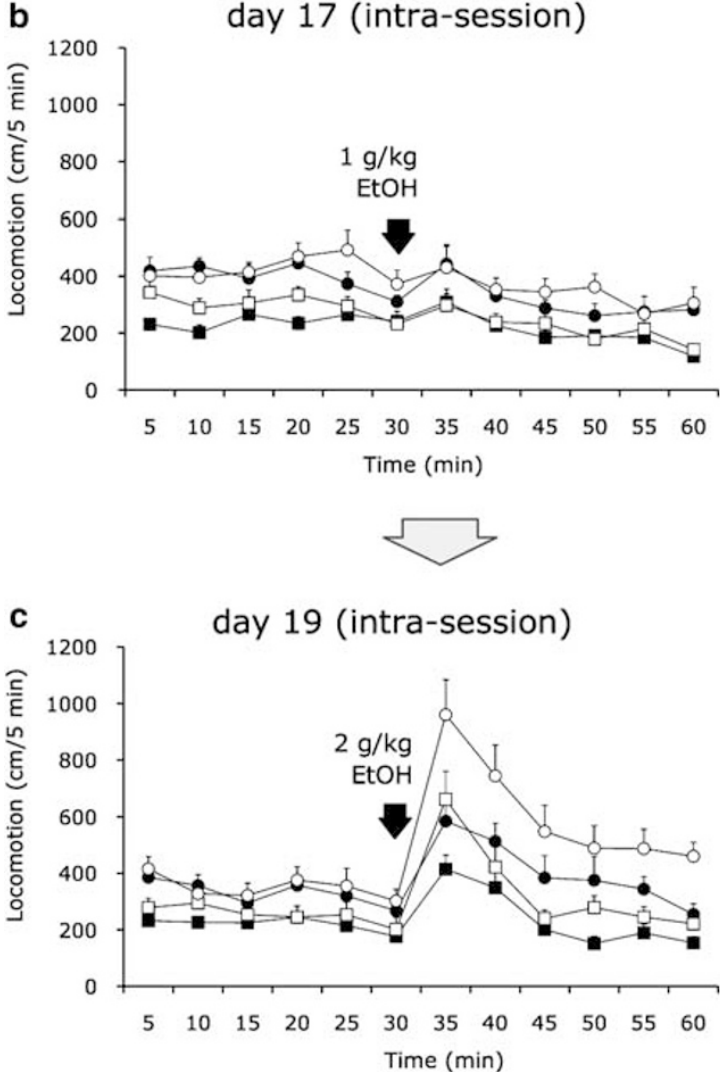

d

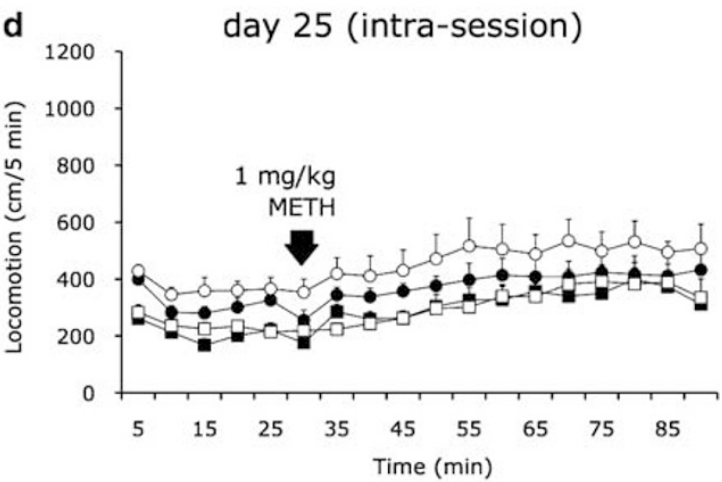

$\sqrt{3}$

e

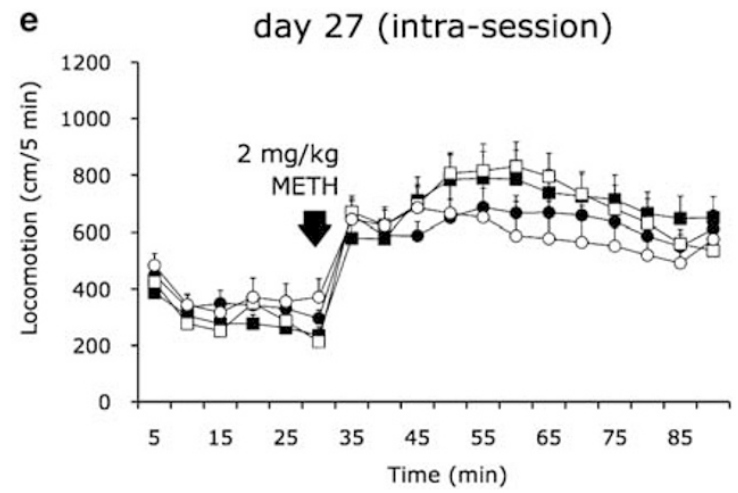

WT-vehicle

WT-EtOH

KO-vehicle

KO-EtOH

Figure 5 Acute and chronic locomotor responses to ethanol in wild type and NOP receptor knockout (KO) mice. Panel a shows the locomotor response of mice treated with vehicle or $2 \mathrm{~g} / \mathrm{kg}$ i.p. ethanol over $10 \mathrm{~min}$ in a novel environment. Three days later, the basal locomotor response of all mice was measured for $30 \mathrm{~min}$ in the same environment before challenge with I g/kg i.p. ethanol and locomotion measured for a further 30 min (day 17 , panel b). Panels b-e show locomotion divided into $5 \mathrm{~min}$ bins. The same procedure was performed with $2 \mathrm{~g} / \mathrm{kg}$ i.p. ethanol 2 days later (panel c: day 19,). Six days later, the basal locomotor response of mice was measured for 30 min and then all mice were challenged with I mg/kg s.c. methamphetamine (METH) to assess cross-sensitized responses (panel d: day 25,). The same procedure was repeated with $2 \mathrm{mg} / \mathrm{kg}$ s.c. METH 2 days later (panel e: day 27). $n=9$ or 10 mice per group. Data are presented as mean \pm SEM. See Results section for the results of statistical analysis.

(Figure 5e). All groups of mice showed a clear stimulatory response to $2 \mathrm{mg} / \mathrm{kg}$ s.c. METH. A significant interaction between daily ethanol treatment on days 1 to 14 and time only was observed $\left(\mathrm{F}_{(11,374)}=2.384, p=0.0073\right)$ as previously ethanol-treated mice showed a dampened stimulatory locomotor response to $2 \mathrm{mg} / \mathrm{kg} \mathrm{METH}$. No interaction with genotype was found.
Experiment 8: Ethanol Preference and Sedative Effects of Ethanol in NOP Receptor KO Mice: Two-Bottle Choice Experiment

No genotype differences in loss-of-righting reflex following $3 \mathrm{~g} / \mathrm{kg}$ ethanol treatment were found (wild type; $1396 \pm 188 \mathrm{~s}, n=11$ and KO; $1232 \pm 147 \mathrm{~s}, n=11$; one mouse 

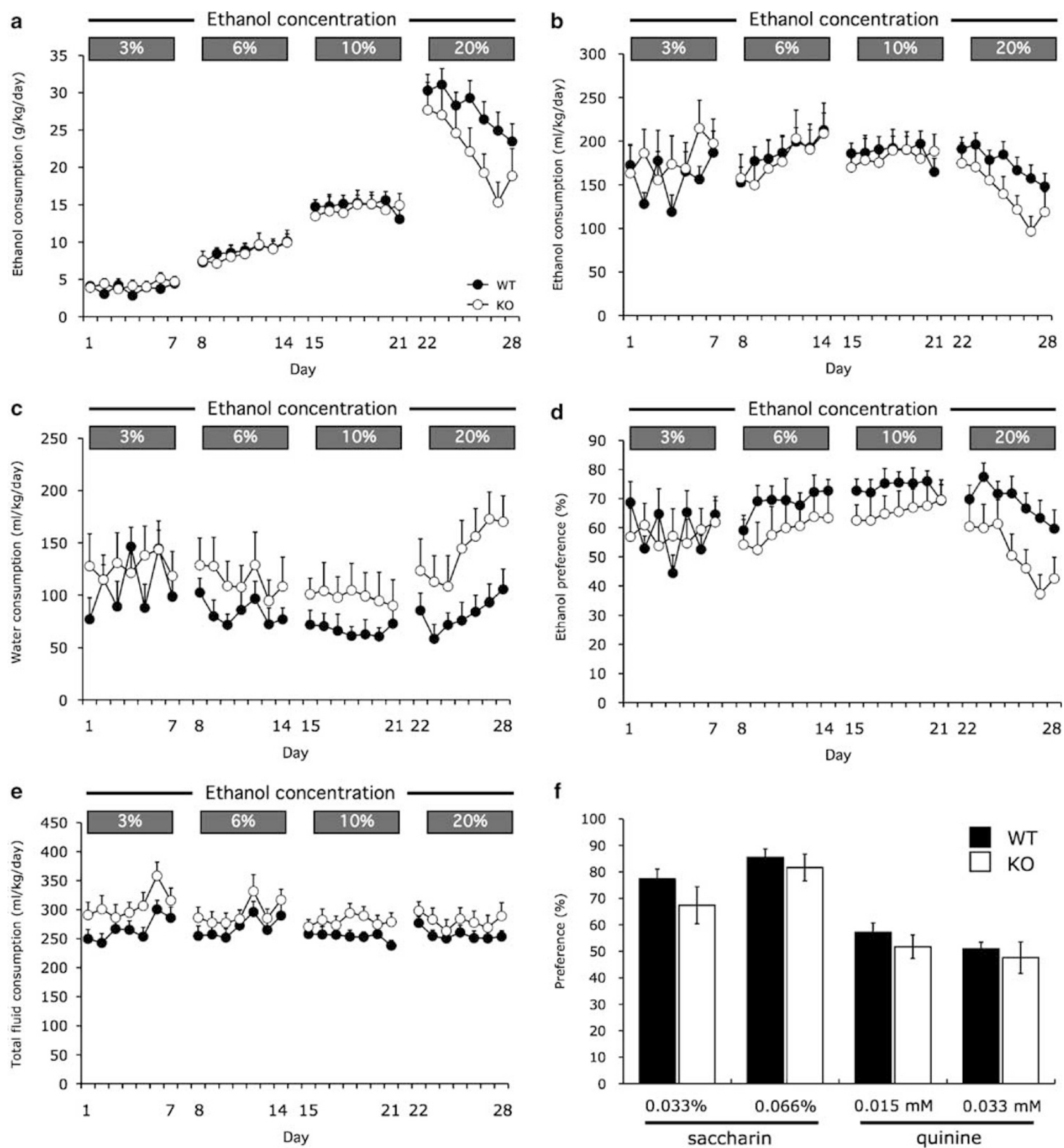

Figure 6 Daily absolute ethanol (a), ethanol solution volume (b), and water intake (c), ethanol preference (d) and total fluid intake (e) in wild type (WT) and NOP receptor knockout $(\mathrm{KO})$ mice under free access conditions in a two-bottle choice paradigm. Panel $\mathrm{f}$ shows preference for saccharin and quinine solutions in wild type and NOP receptor KO mice measured under free access conditions in a bottle choice paradigm. $n=12$ mice per group. Data are presented as mean \pm SEM. See Results section for the results of statistical analysis.

from each genotype group was excluded from analysis as they failed to show a complete loss-of-righting reflex. However, they were included in the subsequent analysis).

Both genotypes escalated their ethanol consumption when presented ethanol in an unrestricted fashion as a choice against water in the two-bottle choice test (Figure 6a). Large increases in ethanol consumption were observed particularly when new (higher) concentrations of ethanol were presented. NOP receptor KO mice showed approximately similar absolute ethanol consumption as wild-type mice during presentation of 3,6 , and $10 \%$ concentrations of ethanol. At the highest concentration of ethanol (20\%), NOP receptor KO mice tended toward lower ethanol consumption, though this was not statistically significant when considered over the entire 7 days of presentation (Figure $6 \mathrm{a}$ and $\mathrm{b}$ ). NOP receptor $\mathrm{KO}$ mice 


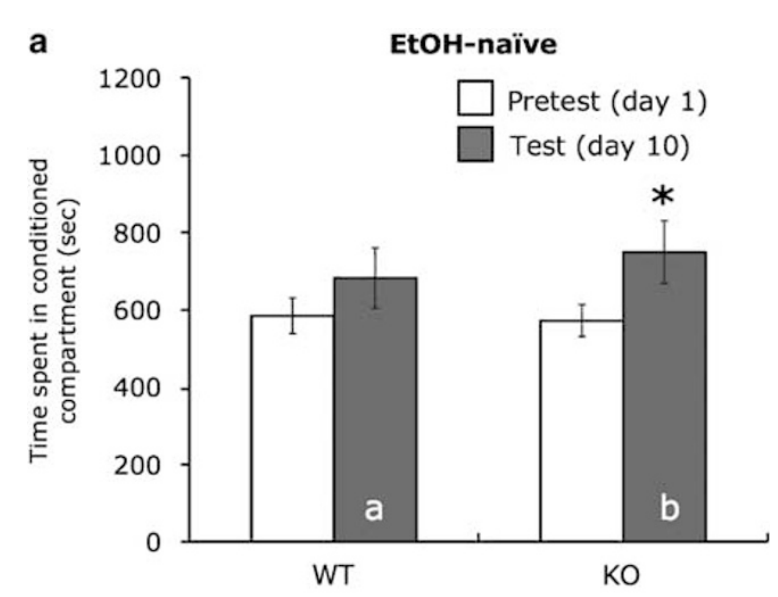

b

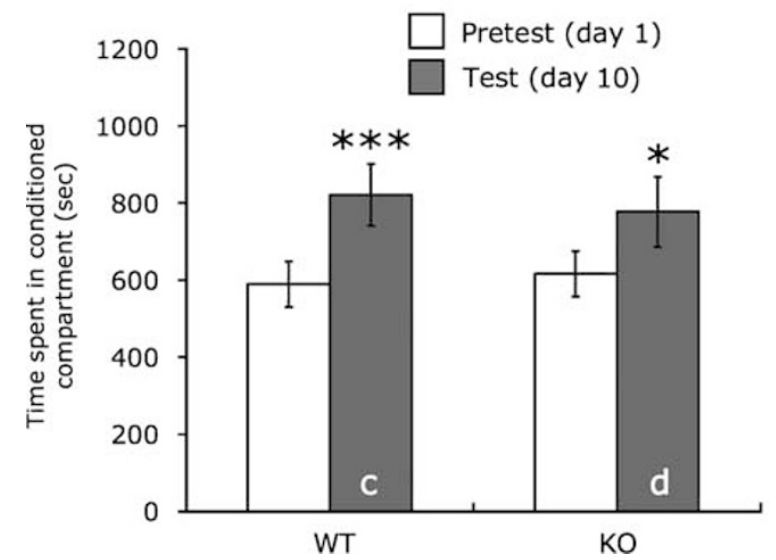

Figure 7 CPP induced by $2 \mathrm{~g} / \mathrm{kg}$ i.p. ethanol in either ethanol-naive (a) or ethanol-experienced (b) NOP receptor knockout (KO) and wild-type (WT) mice. Ethanol-naive (also experimentally naive) mice and mice previously studied serially in the loss-of-righting-reflex, two-bottle ethanol choice test (shown in Figure 6), and taste-reactivity test were conditioned to ethanol separately. Mice were conditioned for 8 days (four vehicle and four $2 \mathrm{mg} / \mathrm{kg}$ i.p. ethanol session). $Y$ axis represents time in the ethanolpaired compartment before (pretest) and after (test) ethanol conditioning. $* p<0.05$ and $* * * * 00.001$ vs corresponding pretest time. Data are presented as mean \pm SEM. $n=12-15$ mice per group. A detailed report of the statistical analyses indicated by the lowercase letter is provided online as Supplementary Information.

tended toward enhanced water intakes compared to wildtype mice, in all sessions (Figure 6c). This became particularly pronounced as the ethanol concentration was increased, such that NOP receptor KO mice drank significantly $\left(\mathrm{F}_{(1,22)}=5.172, p=0.0331\right)$ more water than wild-type mice during presentation of $20 \%$ ethanol. Furthermore, significant effects of time on ethanol consumption $\left(\mathrm{F}_{(6,132)}=8.379, p<0.0001\right)$, water consumption $\left(\mathrm{F}_{(6,132)}=4.383, \quad p=0.0005\right)$, and ethanol preference $\left(\mathrm{F}_{(6,132)}=7.009, p<0.0001\right)$ were found during presentation of $20 \%$ ethanol. This was due to a general decrease in ethanol consumption and ethanol preference during the 7day presentation period, whereas water consumption increased over this time period. When considered as ethanol preference, NOP receptor KO mice tended toward reduced preferences for ethanol during presentation of all but 3\% ethanol solutions (Figure 6d). The reduced preference for ethanol was statistically significant $\left(\mathrm{F}_{(1,22)}=5.314, p=0.0310\right)$ at the $20 \%$ ethanol concentration. Significant genotype difference on total fluid intake was not observed throughout all sessions (Figure 6e). No genotype-dependent differences were found in saccharin or quinine consumption, suggesting that taste reactivity was similar between genotypes (Figure 6f).

Studies in a separate set of ethanol-naive mice (aged 16 weeks) showed that the basal intake of water, but not food, in NOP receptor KO mice housed singularly with ad libitum food presentation was significantly higher (approximately $35 \%$ ) than wild-type mice (wild type, $2.0 \pm 0.5 \mathrm{l} / \mathrm{kg}$ body weight/week, $n=14$; NOP receptor KO, $2.7 \pm 0.6 \mathrm{l} / \mathrm{kg}$ body weight/week, $\left.n=16 ; t_{(28)}=3.760, p=0.0008\right)$.

\section{Experiment 9: Ethanol-Induced Place Preference in NOP Receptor KO Mice}

During conditioning to i.p. $2 \mathrm{~g} / \mathrm{kg}$ ethanol, NOP receptor KO mice showed higher locomotor responses to ethanol (data not shown), as previously observed in Experiment 7. Under the parameters of the conditioning protocol used, only NOP receptor KO mice showed a statistically significant $\left(t_{(13)}=-2.885, p=0.0128\right)$ CPP to conditioning with ethanol among the ethanol-naive mice (Figure 7a). In contrast, a statistically significant CPP (wild type; $t_{(11)}=-5.696, p=0.0001$, NOP receptor KO; $t_{(11)}=$ $-2.395, p=0.0355)$ to ethanol was established in both genotypes of mice that had undergone extensive ethanol consumption in Experiment 8 (Figure $7 \mathrm{~b}$ ).

No genotype-dependent difference in blood ethanol clearance was observed in ethanol-naive mice $(15 \mathrm{~min}$ after $4 \mathrm{~g} / \mathrm{kg}$ ethanol injection: NOP receptor KO, $4.58 \pm 0.15 \mathrm{~g} / \mathrm{l}$, $n=8$; wild type, $4.60 \pm 0.11 \mathrm{~g} / \mathrm{l}, n=7 ; 60 \mathrm{~min}$ after $4 \mathrm{~g} / \mathrm{kg}$ ethanol injection: NOP receptor KO, $4.39 \pm 0.19 \mathrm{~g} / \mathrm{l}, n=6$; wild type, $3.98 \pm 0.19 \mathrm{~g} / \mathrm{l}, n=8)$.

\section{DISCUSSION}

The main findings of the current study may be summarized as follows:

1. The NOP receptor antagonist UFP-101 administered alone induces CPP, and enhances METH-induced CPP. Additionally, METH-induced and ethanol-induced CPP is stronger in NOP receptor $\mathrm{KO}$ than wild-type mice. Together, these results indicate that endogenous N/OFQ suppresses basal and drug-stimulated increases in hedonic state.

2. Behavioral sensitization to repeated intermittent METH treatment is attenuated in NOP receptor KO mice. Additionally, the NOP receptor antagonist UFP-101 mimics this effect (though a strong suppressive effect of UFP-101 must be borne in mind when interpreting these results. See below). These results suggest endogenous N/OFQ plays a permissive or facilitatory role in the plastic changes underlying behavioral sensitization.

3. The strengthening effect of chronic drug treatment on CPP is absent in NOP receptor KO mice, further supporting the view that endogenous N/OFQ facilitates 
the adaptive changes underlying the development of addiction.

4. Preference for ethanol in a two-bottle choice test is lower in NOP receptor KO mice, suggesting that endogenous $\mathrm{N} / \mathrm{OFQ}$ modulates the incentive or rewarding value of ethanol, or the ability to adapt to ethanol drinking. However, interpretation of these findings must be viewed in light of an enhanced baseline water intake observed in NOP receptor KO mice.

These results are summarized in Supplementary Table S1, alongside findings from previous reports of the effect of NOP receptor ligands on drug-related behaviors and the activity of the mesolimbic dopamine system.

\section{Role of Endogenous N/OFQ in Balancing Hedonic State}

The current study shows that blocking the influence of endogenous N/OFQ by either pharmacological (using the NOP receptor antagonist UFP-101) or genetic (NOP receptor KO) means enhances METH- and ethanol-induced CPP. In support of our findings, a previous report described a tendency of NOP receptor KO mice toward stronger ethanol-induced CPP (Kuzmin et al, 2003), though this particular finding was not discussed in detail, possibly because no statistically significant difference from wild-type mice was seen. Indeed when analyzed by the same method as these previous studies, no statistically significant difference in the ethanol-induced place conditioning was found in the current study. However, within groups, ethanol-naive NOP receptor KO mice showed a statistically significant CPP to ethanol in the current study, which was absent in wild-type mice.

Not withstanding an effect of these manipulations on learning and memory (see Taverna et al, 2005 for example and references), these results provide the first evidence that endogenous N/OFQ buffers the hedonic state of the brain and counteracts the positive hedonic state induced by rewarding drugs. These results are consistent with previous studies showing that exogenous N/OFQ administration suppresses the acquisition or expression of drug-induced CPP (Ciccocioppo et al, 1999, 2000; Murphy et al, 1999; Kotlinska et al, 2003; Kuzmin et al, 2003; Zhao et al, 2003; Sakoori and Murphy, 2004).

These findings are particularly interesting when viewed in the light of other opioid peptides, ie those acting at $\mu$ (MOP), $\delta$ (DOP), or $\kappa$-opioid receptors. All of these peptides have been implicated in the hedonic responses of rewarding and aversive stimuli (Pan, 1998; Kieffer and Gaveriaux-Ruff, 2002). Activation of neural circuits expressing MOP receptors is necessary for many, if not all, rewarding drugs to exert their hedonic impact (eg Berrendero et al, 2002; Contarino et al, 2002; Hall et al, 2004). In contrast, activation of neural circuits bearing KOP receptors appears to suppress drug reward, and possibly mediate aversive states (see Pan, 1998). Opioid receptors, including NOP receptors, are widely, but differentially distributed in the brain. Several studies using opioid-stimulated $\left[{ }^{35} \mathrm{~S}\right] \mathrm{GTP} \gamma \mathrm{S}$ binding have shown that activation of the amygdala, thalamus, and hypothalamus is common to MOP, KOP, and NOP receptor agonists (Shimohira et al, 1997; Sim and Childers, 1997). All of these areas are believed to be involved in mediating drug reward (Bardo, 1998), and may represent a converging point at which endogenous opioids balance hedonic state.

\section{Role of Endogenous N/OFQ in Behavioral Sensitization}

In contrast to the suppressive effect of endogenous N/OFQ on the acquisition and/or expression of CPP, endogenous N/OFQ appears to either facilitate, or at least permit, the development of behavioral sensitization to METH. That is, genetic deletion of NOP receptors, or administration of an NOP receptor antagonist retarded the development of METH-induced behavioral sensitization. Until now, apparently conflicting results regarding the effect of exogenous N/ OFQ on behavioral sensitization to psychostimulants have been reported. Initial studies (in rats) showed that single (Narayanan and Maidment, 1999) or repeated (Narayanan et al, 2002) administration of N/OFQ into the ventral tegmental area (the source of mesocorticolimbic dopamine neurons) cross-sensitizes the locomotor response to subsequent cocaine administration. Contrasting with these were subsequent studies showing that escalating doses of i.c.v.-administered N/OFQ suppresses behavioral sensitization to cocaine (Lutfy et al, 2002) or amphetamine (Kotlinska et al, 2003). However, in our previous studies of behavioral sensitization to a smaller number of METH administrations, we found nonsignificant tendencies toward attenuated rates of sensitization in NOP receptor KO mice (Okabe et al, 2005). Overall, the current study supports previous studies indicating a permissive or facilitatory role of endogenous N/OFQ in the development of behavioral sensitization to psychostimulant drugs, though the obvious question is, how could this occur?

Behavioral sensitization to psychostimulant drugs is accompanied by various morphological changes in the spines and dendritic branches of neurons in several brain regions, including the hippocampus and nucleus accumbens (Li et al, 2003, 2004). Indeed, the precursor peptide of N/OFQ was originally discovered by subtraction cloning of the mouse NS20Y cell line undergoing dibutyryl cyclic AMP-stimulated neurite outgrowth (see Saito et al, 1997). Considering the origin of N/OFQ peptide, endogenous N/ OFQ may facilitate such morphological changes that result from chronic drug administration.

An alternative or additional mechanism of action of endogenous N/OFQ could take place in the frontal cortex, where dopamine content has been reported to be lower in NOP receptor KO mice (Mamiya et al, 1998). As 6hydroxydopamine lesions of the prefrontal cortex prevent development of amphetamine-induced behavioral sensitization (Bjijou et al, 2002), the retarded behavioral sensitization to METH seen here could result from a deficiency in prefrontal dopamine. Typically, perturbations to the prefrontal cortex, such as produced by chemical lesions, are only mildly detrimental to the acquisition and expression of CPP (eg Zavala et al, 2003), but have particularly strong effects on relapse behavior. The results of the current study are noteworthy, as NOP receptor KO mice have generally stronger METH-induced CPP, despite showing attenuated behavioral sensitization.

A third possible explanation for the attenuated rate of behavioral sensitization to METH in NOP receptor KO mice 
could be related to the involvement of neurotrophic factors such as neurotrophin-3, brain-derived neurotrophic factor (BDNF), ciliary neurotrophic factor (CNTF), basic fibroblast growth factor and glial-derived neurotrophic factor (GDNF) in plastic changes. Recent studies show that all of these neurotrophic factors, except GDNF, positively modulate behavioral sensitization, whereas GDNF itself has a negative effect (Pierce and Bari, 2001). Both BDNF application to hippocampal cultures (Ring et al, 2006) and CNTF application to striatal cultures (Buzas et al, 1999) induce the expression of mRNA for N/OFQ, suggesting that endogenous N/OFQ could mediate the effect of these factors on behavioral sensitization. This possibility remains to be tested.

It is notable that UFP-101 itself suppressed locomotion in our studies; an effect that may seem contradictory to expectation, particularly as studies in other strains of mice have not found a similar effect (Gavioli et al, 2003; Kuzmin et al, 2004). However, several previous studies (eg Florin et al, 1996; Sakoori and Murphy, 2004) show that i.c.v. administration of N/OFQ has a biphasic effect on locomotion in mice, with lower doses stimulating, and higher doses suppressing locomotion. It is possible that in C57BL6 mice, UFP-101 at the doses used in the current study antagonizes an endogenous $\mathrm{N} / \mathrm{OFQ}$ tone that normally supports locomotor behavior.

In this study, NOP receptor KO mice showed stronger CPP, but weaker behavioral sensitization. Typically, psychostimulant drugs induce both $\mathrm{CPP}$ and behavioral sensitization (see Orsini et al, 2004). To our knowledge, only mice lacking MOP receptors contradict this generalization, as they display lower cocaine-induced CPP, yet show enhanced cocaine-induced behavioral sensitization (Hall et al, 2004). This phenotype is precisely the opposite of that of NOP receptor KO in the current study, and supports the suggestion that MOP and NOP systems act antagonistically in reward and addiction processes (Murphy, 2004).

\section{Endogenous N/OFQ and Voluntary Ethanol Consumption}

In this study, NOP receptor KO mice had a lower preference for ethanol than wild-type mice. However, a disturbed water balance in NOP receptor KO mice complicated interpretation of the ethanol consumption studies presented here. While this finding is surprising in light of the growing number of studies predicting that loss of endogenous N/OFQ function would lead to more efficient water retention (see Kapusta, 2000 for review), it is well supported by other studies using an antisense oligonucleotide approach (Blakley et al, 2004). Genotype-dependent differences in water balance have complicated previous studies of voluntary ethanol consumption in receptor $\mathrm{KO}$ mice (Bouwknecht et al, 2000; Chu et al, 2004; Thiele et al, 2004), and this has also known to be gender specific (Hungund et al, 2003).

Most previous studies show exogenous N/OFQ administration suppresses ethanol preference, intake, and reinforcement (Ciccocioppo et al, 1999, 2002, 2004a, 2006), though preliminary reports elsewhere using a pharmacological approach support our findings, as administration of the peptide NOP receptor antagonist UFP-101 also tends to reduce voluntary ethanol consumption (Ciccocioppo et al, 2004b). The lower voluntary ethanol consumption displayed by NOP receptor KO mice in the current study could be interpreted as the endogenous $\mathrm{N} / \mathrm{OFQ}$ systems being necessary for ethanol reward to take place. However, alternative interpretations exist. For example, mice with genetic ablations of MOP receptors have reduced voluntary ethanol consumption and CPP (Hall et al, 2001), which is consistent with animal (see Hall et al, 2001 for references) and human (Davidson et al, 1999) studies showing antagonism of MOP receptors reduces ethanol reward. These studies suggest that MOP receptors mediate ethanolinduced reward. However, it is arguable that if the hedonic impact of ethanol is reduced by genetic or pharmacological manipulations, then higher levels of ethanol consumption, rather than lower, may be expected, in an effort to compensate for a reduced (positive) hedonic impact. Indeed, mice lacking DOP receptors display enhanced voluntary consumption of ethanol (Roberts et al, 2001), yet activation of DOP receptors is also rewarding (Longoni et al, 1998). Alternatively, some more fundamental, perhaps toxic, response to ethanol may be altered in NOP receptor $\mathrm{KO}$ mice. Indeed, our other studies find that the hypothermic response to ethanol is accentuated in NOP receptor KO mice (Sakoori and Murphy, unpublished observation).

One possible explanation for the inconsistency between previous studies and the current study may lie in differences between the acute and chronic effects of N/OFQ on ethanol intake. Recently Cifani and colleagues reported that chronic infusion of N/OFQ increases ethanol intake; opposite to previous reports using acute injection of N/OFQ (Cifani et al, 2006). Our current result supports this finding. Similar seemingly inconsistent findings between pharmacological and genetic manipulations are observed in studies of the KOP system, where administration of KOP antagonists is found to enhance ethanol consumption (Mitchell et al, 2005), yet KOP receptor KO mice consume less ethanol than wild-type mice (Kovacs et al, 2005).

\section{Endogenous N/OFQ and the Plastic Changes that Underlie the Chronic Effects of Addictive Drugs}

A key finding of the current study is that not only does endogenous N/OFQ appears to acutely suppress drug reward, but also plays a key role in the plastic changes that could underlie the development of addiction. This is not only evident in the behavioral sensitization studies, but also in the CPP studies performed following behavioral sensitization.

What could be the relationship between the endogenous N/OFQ-NOP receptor system and the chronic effect of addictive drugs? Recent studies show that genetic ablation of NOP receptors or NOP precursor is neuroprotective to dopamine neurons (Marti et al, 2005; Brown et al, 2006). This is particularly interesting in light of several studies suggesting that damage to dopaminergic systems could underlie many of the behavioral effects of chronic drug administration. For instance, dopaminergic systems appear to be hypoactive during and after withdrawal from chronic drug treatment, as indicated by reduced D2-dopamine 
receptors and dopamine release (see Melis et al, 2005). Furthermore, reduced dopaminergic terminals in the prefrontal cortex accompany sensitization to METH (Kadota and Kadota, 2004). Although conflicting results have been reported, administration of neurotoxic doses of METH alters subsequent acquisition and expression of METHinduced CPP (eg Itzhak et al, 2002; Gehrke et al, 2003; Achat-Mendes et al, 2005). Deliberate dopaminergic lesions induced by injection of 6-hyroxydopamine are largely suppressive to behavioral sensitization (Bjijou et al, 2002) and CPP (Sellings and Clarke, 2006) to METH and affect ethanol preference and consumption (Quarfordt et al, 1991; Fahlke et al, 1994). It seems likely that endogenous N/OFQ may therefore facilitate the neurotoxic effects of abused drugs on dopamine systems, and in this sense endogenous N/OFQ may act to 'promote' drug addiction.

In support of these findings, it is notable that previous studies have shown that both NOP receptor KO (Ueda et al, 2000) and N/OFQ precursor KO (Chung et al, 2006) mice fail to develop tolerance to chronic morphine administration. Similar results are seen following administration of the NOP receptor antagonists (Zaratin et al, 2004; Chung et al, 2006). Additionally, mice with null mutations of the N/OFQ gene adapt poorly to repeated stress (Koster et al, 1999). Alongside the results of the current studies, these studies further support the hypothesis that endogenous N/OFQ plays a critical role in adaptive responses, such as to repeated administration of addictive drugs.

Our previous studies show that turnover of dopamine in the mesolimbic system is virtually unchanged in drug-naive NOP receptor KO mice (Koizumi et al, 2004b), as is the acute stimulatory response to heroin (Murphy et al, 2002) and cocaine (Murphy et al, unpublished observation). Furthermore, the locomotor response to acute heroin administration (Murphy et al, 2002), as well as METH (current study) is also unchanged. However, the current study shows that with repeated administration, reduced sensitized locomotor responses become clear. It is interesting to speculate that differences in the responsiveness of the mesolimbic dopamine to addictive drugs would manifest themselves following chronic repeated administration.

\section{Conclusion}

The current study shows that endogenous N/OFQ suppresses the hedonic state of the brain and facilitates the long-term alterations induced by chronic METH and ethanol administration. These findings suggest that targeting the N/OFQ-NOP receptor system could have therapeutic applications for the treatment of drug addiction though a careful consideration would need to be given to the longterm effects such treatments might have.

\section{ACKNOWLEDGEMENTS}

We thank Professor Hiroshi Takeshima for the generous gift of NOP receptor KO progenitor mice and Professor Nigel Maidment and Dr Barbara Cagniard and Dr Adam Weitemier for critical reading of the manuscript.

\section{DISCLOSURE/CONFLICT OF INTEREST}

We declare no conflict of interests.

\section{REFERENCES}

Achat-Mendes C, Ali SF, Itzhak Y (2005). Differential effects of amphetamines-induced neurotoxicity on appetitive and aversive Pavlovian conditioning in mice. Neuropsychopharmacology 30: 1128-1137.

Bardo MT (1998). Neuropharmacological mechanisms of drug reward: beyond dopamine in the nucleus accumbens. Crit Rev Neurobiol 12: 37-67.

Bardo MT, Bevins RA (2000). Conditioned place preference: what does it add to our preclinical understanding of drug reward? Psychopharmacology (Berl) 153: 31-43.

Berrendero F, Kieffer BL, Maldonado R (2002). Attenuation of nicotine-induced antinociception, rewarding effects, and dependence in mu-opioid receptor knock-out mice. J Neurosci 22: 10935-10940.

Bjijou Y, De Deurwaerdere P, Spampinato U, Stinus L, Cador M (2002). D-amphetamine-induced behavioral sensitization: effect of lesioning dopaminergic terminals in the medial prefrontal cortex, the amygdala and the entorhinal cortex. Neuroscience 109: 499-516.

Blakley GG, Pohorecky LA, Benjamin D (2004). Behavioral and endocrine changes following antisense oligonucleotide-induced reduction in the rat NOP receptor. Psychopharmacology (Berl) 171: 421-428.

Bouwknecht JA, Hijzen TH, van der Gugten J, Maes RA, Hen R, Olivier B (2000). Ethanol intake is not elevated in male 5-HT(1B) receptor knockout mice. Eur J Pharmacol 403: 95-98.

Brown JM, Gouty S, Iyer V, Rosenberger J, Cox BM (2006). Differential protection against MPTP or methamphetamine toxicity in dopamine neurons by deletion of ppN/OFQ expression. J Neurochem 98: 495-505.

Buzas B, Symes AJ, Cox BM (1999). Regulation of nociceptin/ orphanin FQ gene expression by neuropoietic cytokines and neurotrophic factors in neurons and astrocytes. J Neurochem 72 : 1882-1889.

Chu CP, Kunitake T, Kato K, Watanabe S, Qiu DL, Tanoue A et al (2004). The alpha 1D-adrenergic receptor modulates cardiovascular and drinking responses to central salt loading in mice. Neurosci Lett 356: 33-36.

Chung S, Pohl S, Zeng J, Civelli O, Reinscheid RK (2006). Endogenous orphanin FQ/nociceptin is involved in the development of morphine tolerance. J Pharmacol Exp Ther 318: 262-267.

Ciccocioppo R, Angeletti S, Sanna PP, Weiss F, Massi M (2000). Effect of nociceptin/orphanin FQ on the rewarding properties of morphine. Eur J Pharmacol 404: 153-159.

Ciccocioppo R, Economidou D, Fedeli A, Angeletti S, Weiss F, Heilig M et al (2004a). Attenuation of ethanol self-administration and of conditioned reinstatement of alcohol-seeking behaviour by the antiopioid peptide nociceptin/orphanin FQ in alcohol-preferring rats. Psychopharmacology (Berl) 172: $170-178$.

Ciccocioppo R, Economidou D, Fedeli A, Heilig M, Massi M (2004b). Inhibition of ethanol drinking by buprenorphine: evidence for the involvement of the nociceptin/orphanin $\mathrm{fq}$ receptor system. 2004 Abstract Viewer/Itinerary Planner. Society for Neuroscience: Washington, DC, 2004. Online. Program No. 691.10.

Ciccocioppo R, Economidou D, Fedeli A, Massi M (2003). The nociceptin/orphanin $\mathrm{FQ} / \mathrm{NOP}$ receptor system as a target for treatment of alcohol abuse: a review of recent work in alcoholpreferring rats. Physiol Behav 79: 121-128. 
Ciccocioppo R, Economidou D, Rimondini R, Sommer W, Massi $M$, Heilig $M$ (2006). Buprenorphine reduces alcohol drinking through activation of the nociceptin/orphanin FQ-NOP receptor system. Biol Psychiatry 6: 4-12.

Ciccocioppo R, Panocka I, Polidori C, Regoli D, Massi M (1999). Effect of nociceptin on alcohol intake in alcohol-preferring rats. Psychopharmacology (Berl) 141: 220-224.

Ciccocioppo R, Polidori C, Antonelli L, Salvadori S, Guerrini R, Massi M (2002). Pharmacological characterization of the nociceptin receptor which mediates reduction of alcohol drinking in rats. Peptides 23: 117-125.

Cifani C, Guerrini R, Massi M, Polidori C (2006). Chronic intracerebroventricular infusion of nociceptin/orphanin FQ increases food and ethanol intake in alcohol-preferring rats. Peptides 27: 2803-2810.

Contarino A, Picetti R, Matthes HW, Koob GF, Kieffer BL, Gold LH (2002). Lack of reward and locomotor stimulation induced by heroin in mu-opioid receptor-deficient mice. Eur J Pharmacol 446: 103-109.

Davidson D, Palfai T, Bird C, Swift R (1999). Effects of naltrexone on alcohol self-administration in heavy drinkers. Alcohol Clin Exp Res 23: 195-203.

Di Giannuario A, Pieretti S, Catalani A, Loizzo A (1999). Orphanin FQ reduces morphine-induced dopamine release in the nucleus accumbens: a microdialysis study in rats. Neurosci Lett 272: 183-186.

Economidou D, Fedeli A, Fardon RM, Weiss F, Massi M, Ciccocioppo R (2006). Effect of novel nociceptin/orphanin FQNOP receptor ligands on ethanol drinking in alcohol-preferring msP rats. Peptides 27: 3299-3306.

Fahlke C, Hansen S, Engel JA, Hard E (1994). Effects of ventral striatal 6-OHDA lesions or amphetamine sensitization on ethanol consumption in the rat. Pharmacol Biochem Behav 47: 345-349.

Florin S, Suaudeau C, Meunier JC, Costentin J (1996). Nociceptin stimulates locomotion and exploratory behaviour in mice. Eur $J$ Pharmacol 317: 9-13.

Gavioli EC, Marzola G, Guerrini R, Bertorelli R, Zucchini S, De Lima TC et al (2003). Blockade of nociceptin/orphanin FQ-NOP receptor signalling produces antidepressant-like effects: pharmacological and genetic evidences from the mouse forced swimming test. Eur J Neurosci 17: 1987-1990.

Gehrke BJ, Harrod SB, Cass WA, Bardo MT (2003). The effect of neurotoxic doses of methamphetamine on methamphetamineconditioned place preference in rats. Psychopharmacology (Berl) 166: 249-257.

Hall FS, Goeb M, Li XF, Sora I, Uhl GR (2004). mu-Opioid receptor knockout mice display reduced cocaine conditioned place preference but enhanced sensitization of cocaine-induced locomotion. Brain Res Mol Brain Res 121: 123-130.

Hall FS, Sora I, Uhl GR (2001). Ethanol consumption and reward are decreased in mu-opiate receptor knockout mice. Psychopharmacology (Berl) 154: 43-49.

Hungund BL, Szakall I, Adam A, Basavarajappa BS, Vadasz C (2003). Cannabinoid CB1 receptor knockout mice exhibit markedly reduced voluntary alcohol consumption and lack alcohol-induced dopamine release in the nucleus accumbens. J Neurochem 84: 698-704.

Itzhak Y, Martin JL, Ali SF (2002). Methamphetamine-induced dopaminergic neurotoxicity in mice: long-lasting sensitization to the locomotor stimulation and desensitization to the rewarding effects of methamphetamine. Prog Neuropsychopharmacol Biol Psychiatry 26: 1177-1183.

Kadota T, Kadota K (2004). Neurotoxic morphological changes induced in the medial prefrontal cortex of rats behaviorally sensitized to methamphetamine. Arch Histol Cytol 67: 241-251.

Kapusta DR (2000). Neurohumoral effects of orphanin FQ/ nociceptin: relevance to cardiovascular and renal function. Peptides 21: 1081-1099.
Kieffer BL, Gaveriaux-Ruff C (2002). Exploring the opioid system by gene knockout. Prog Neurobiol 66: 285-306.

Koizumi M, Midorikawa N, Takeshima H, Murphy NP (2004a). Exogenous, but not endogenous nociceptin modulates mesolimbic dopamine release in mice. J Neurochem 89: 257-263.

Koizumi M, Sakoori K, Midorikawa N, Murphy NP (2004b). The NOP (ORL1) receptor antagonist Compound B stimulates mesolimbic dopamine release and is rewarding in mice by a non-NOP-receptor-mediated mechanism. $\mathrm{Br} J$ Pharmacol 143: 53-62.

Koster A, Montkowski A, Schulz S, Stube EM, Knaudt K, Jenck F et al (1999). Targeted disruption of the orphanin FQ/nociceptin gene increases stress susceptibility and impairs stress adaptation in mice. Proc Natl Acad Sci USA 96: 10444-10449.

Kotlinska J, Rafalski P, Biala G, Dylag T, Rolka K, Silberring J (2003). Nociceptin inhibits acquisition of amphetamine-induced place preference and sensitization to stereotypy in rats. Eur $J$ Pharmacol 474: 233-239.

Kovacs KM, Szakall I, O’Brien D, Wang R, Vinod KY, Saito M et al (2005). Decreased oral self-administration of alcohol in kappa-opioid receptor knock-out mice. Alcohol Clin Exp Res 29: 730-738.

Kuzmin A, Sandin J, Terenius L, Ogren SO (2003). Acquisition, expression, and reinstatement of ethanol-induced conditioned place preference in mice: effects of opioid receptor-like 1 receptor agonists and naloxone. J Pharmacol Exp Ther 304: 310-318.

Kuzmin A, Sandin J, Terenius L, Ogren SO (2004). Evidence in locomotion test for the functional heterogeneity of ORL-1 receptors. Br J Pharmacol 141: 132-140.

Lett BT (1989). Repeated exposures intensify rather than diminish the rewarding effects of amphetamine, morphine, and cocaine. Psychopharmacology (Berl) 98: 357-362.

Li Y, Acerbo MJ, Robinson TE (2004). The induction of behavioural sensitization is associated with cocaine-induced structural plasticity in the core (but not shell) of the nucleus accumbens. Eur J Neurosci 20: 1647-1654.

Li Y, Kolb B, Robinson TE (2003). The location of persistent amphetamine-induced changes in the density of dendritic spines on medium spiny neurons in the nucleus accumbens and caudate-putamen. Neuropsychopharmacology 28: 1082-1085.

Longoni R, Cadoni C, Mulas A, Di Chiara G, Spina L (1998). Dopamine-dependent behavioural stimulation by non-peptide delta opioids BW373U86 and SNC 80: 2. Place-preference and brain microdialysis studies in rats. Behav Pharmacol 9: 9-14.

Lutfy K, Do T, Maidment NT (2001). Orphanin FQ/nociceptin attenuates motor stimulation and changes in nucleus accumbens extracellular dopamine induced by cocaine in rats. Psychopharmacology (Berl) 154: 1-7.

Lutfy K, Khaliq I, Carroll FI, Maidment NT (2002). Orphanin FQ/nociceptin blocks cocaine-induced behavioral sensitization in rats. Psychopharmacology (Berl) 164: 168-176.

Mamiya T, Noda Y, Nishi M, Takeshima H, Nabeshima T (1998). Enhancement of spatial attention in nociceptin/orphanin FQ receptor-knockout mice. Brain Res 783: 236-240.

Marti M, Mela F, Fantin M, Zucchini S, Brown JM, Witta J et al (2005). Blockade of nociceptin/orphanin FQ transmission attenuates symptoms and neurodegeneration associated with Parkinson's disease. J Neurosci 25: 9591-9601.

Melis M, Spiga S, Diana M (2005). The dopamine hypothesis of drug addiction: hypodopaminergic state. Int Rev Neurobiol 63: 101-154.

Mitchell JM, Liang MT, Fields HL (2005). A single injection of the kappa opioid antagonist norbinaltorphimine increases ethanol consumption in rats. Psychopharmacology (Berl) 182: 384-392.

Murphy NP (2004). Nociceptin/orphanin FQ, hedonic state and the response to abused drugs. Nihon Shinkei Seishin Yakurigaku Zasshi 24: 295-298. 
Murphy NP, Lam HA, Chen Z, Pintar JE, Maidment NT (2002). Heroin-induced locomotion and mesolimbic dopamine release is unchanged in mice lacking the ORL.1 receptor gene. Brain Res 953: $276-280$.

Murphy NP, Lee Y, Maidment NT (1999). Orphanin FQ/nociceptin blocks acquisition of morphine place preference. Brain Res 832: 168-170.

Narayanan S, Lutfy K, Maidment N (2002). Sensitization to cocaine after a single intra-cerebral injection of orphanin $\mathrm{FQ} /$ nociceptin. Behav Brain Res 131: 97-103.

Narayanan S, Maidment NT (1999). Orphanin FQ and behavioral sensitization to cocaine. Pharmacol Biochem Behav 63: 271-277.

Nishi M, Houtani T, Noda Y, Mamiya T, Sato K, Doi T et al (1997). Unrestrained nociceptive response and disregulation of hearing ability in mice lacking the nociceptin/orphaninFQ receptor. EMBO J 16: 1858-1864.

Okabe C, Takeshima H, Murphy NP (2005). Methamphetamine sensitization in nociceptin receptor knockout mice: locomotor and c-fos expression. Eur J Pharmacol 507: 57-67.

Orsini C, Buchini F, Piazza PV, Puglisi-Allegra S, Cabib S (2004). Susceptibility to amphetamine-induced place preference is predicted by locomotor response to novelty and amphetamine in the mouse. Psychopharmacology (Berl) 172: 264-270.

Pan ZZ (1998). mu-Opposing actions of the kappa-opioid receptor. Trends Pharmacol Sci 19: 94-98.

Pierce RC, Bari AA (2001). The role of neurotrophic factors in psychostimulant-induced behavioral and neuronal plasticity. Rev Neurosci 12: 95-110.

Quarfordt SD, Kalmus GW, Myers RD (1991). Ethanol drinking following 6-OHDA lesions of nucleus accumbens and tuberculum olfactorium of the rat. Alcohol 8: 211-217.

Reinscheid RK (2006). The orphanin FQ/nociceptin receptor as a novel drug target in psychiatric disorders. CNS Neurol Disord Drug Targets 5: 219-224.

Ring RH, Alder J, Fennell M, Kouranova E, Black IB, ThakkerVaria S (2006). Transcriptional profiling of brain-derivedneurotrophic factor-induced neuronal plasticity: a novel role for nociceptin in hippocampal neurite outgrowth. J Neurobiol 66: 361-377.

Roberts AJ, Gold LH, Polis I, McDonald JS, Filliol D, Kieffer BL et al (2001). Increased ethanol self-administration in delta-opioid receptor knockout mice. Alcohol Clin Exp Res 25: 1249-1256.

Robinson TE, Berridge KC (2001). Incentive-sensitization and addiction. Addiction 96: 103-114.

Saito Y, Maruyama K, Saido TC, Kawashima S (1997). Overexpression of a neuropeptide nociceptin/orphanin FQ precursor gene, $\mathrm{N} 23 \mathrm{~K} / \mathrm{N} 27 \mathrm{~K}$, induces neurite outgrowth in mouse NS20Y cells. J Neurosci Res 48: 397-406.

Sakoori K, Murphy NP (2004). Central administration of nociceptin/orphanin FQ blocks the acquisition of conditioned place preference to morphine and cocaine, but not conditioned place aversion to naloxone in mice. Psychopharmacology (Berl) 172: $129-136$

Sakoori K, Murphy NP (2005). Maintenance of conditioned place preferences and aversion in C57BL6 mice: effects of repeated and drug state testing. Behav Brain Res 160: 34-43.

Sellings LH, Clarke PB (2006). 6-Hydroxydopamine lesions of nucleus accumbens core abolish amphetamine-induced conditioned activity. Synapse 59: 374-377.

Shimohira I, Tokuyama S, Himeno A, Niwa M, Ueda H (1997). Characterization of nociceptin-stimulated in situ [35S]GTPgammaS binding in comparison with opioid agonist-stimulated ones in brain regions of the mice. Neurosci Lett 237: 113-116.

Shippenberg TS, Heidbreder C (1995a). Sensitization to the conditioned rewarding effects of cocaine: pharmacological and temporal characteristics. J Pharmacol Exp Ther 273: 808-815.

Shippenberg TS, Heidbreder C (1995b). The delta-opioid receptor antagonist naltrindole prevents sensitization to the conditioned rewarding effects of cocaine. Eur J Pharmacol 280: 55-61.

Shoblock JR, Wichmann J, Maidment NT (2005). The effect of a systemically active ORL-1 agonist, Ro 64-6198, on the acquisition, expression, extinction, and reinstatement of morphine conditioned place preference. Neuropharmacology 49: 439-446.

Sim LJ, Childers SR (1997). Anatomical distribution of mu, delta, and kappa opioid- and nociceptin/orphanin FQ-stimulated [35S]guanylyl-5'-O-(gamma-thio)-triphosphate binding in guinea pig brain. J Comp Neurol 386: 562-572.

Taverna FA, Georgiou J, McDonald RJ, Hong NS, Kraev A, Salter MW et al (2005). Defective place cell activity in nociceptin receptor knockout mice with elevated NMDA receptor-dependent long-term potentiation. J Physiol 565: 579-591.

Thiele TE, Naveilhan P, Ernfors P (2004). Assessment of ethanol consumption and water drinking by NPY Y(2) receptor knockout mice. Peptides 25: 975-983.

Ueda H, Inoue M, Takeshima H, Iwasawa Y (2000). Enhanced spinal nociceptin receptor expression develops morphine tolerance and dependence. J Neurosci 20: 7640-7647.

Zaratin PF, Petrone G, Sbacchi M, Garnier M, Fossati C, Petrillo P et al (2004). Modification of nociception and morphine tolerance by the selective opiate receptor-like orphan receptor antagonist (-)-cis-1-methyl-7-[[4-(2,6-dichlorophenyl)piperidin-1-yl]methyl]-6,7,8,9-tetrahydro-5H-benzocyclohepten-5-ol (SB-612111). J Pharmacol Exp Ther 308: 454-461.

Zavala AR, Weber SM, Rice HJ, Alleweireldt AT, Neisewander JL (2003). Role of the prelimbic subregion of the medial prefrontal cortex in acquisition, extinction, and reinstatement of cocaineconditioned place preference. Brain Res 990: 157-164.

Zhao RJ, Woo RS, Jeong MS, Shin BS, Kim DG, Kim KW (2003). Orphanin FQ/nociceptin blocks methamphetamine place preference in rats. Neuroreport 14: 2383-2385.

Supplementary Information accompanies the paper on the Neuropsychopharmacology web site (http://www.nature.com/npp) 